\title{
SECURITIZED AND CRIMINALIZED: \\ AN ANALYSIS OF MEXICO'S ADDITION TO THE LIST OF DESIGNATED COUNTRIES OF ORIGIN
}

by

Meredith Baker, BA, University of British Columbia, 2008

\author{
A Major Research Paper \\ presented to Ryerson University \\ in partial fulfillment of the \\ requirements for the degree of \\ Master of Arts \\ in the Program of \\ Immigration and Settlement Studies
}

Toronto, Ontario, Canada, 2014

(C) Meredith Baker 2014 


\section{AUTHOR'S DECLARATION FOR ELECTRONIC SUBMISSION OF A MAJOR RESEARCH PAPER (MRP)}

I hereby declare that I am the sole author of this Major Research Paper. This is a true copy of the MRP, including any required final revisions, as accepted by my examiners.

I authorize Ryerson University to lend this MRP to other institutions or individuals for the purpose of scholarly research.

I further authorize Ryerson University to reproduce this MRP by photocopying or by other means, in total or in part, at the request of other institutions or individuals for the purpose of scholarly research.

I understand that my MRP may be made electronically available to the public.

Meredith Baker 


\title{
SECURITIZED AND CRIMINALIZED: AN ANALYSIS OF MEXICO'S ADDITION TO THE LIST OF DESIGNATED COUNTRIES OF ORIGIN
}

\author{
Meredith Baker \\ Master of Arts, 2014 \\ Immigration and Settlement Studies \\ Ryerson University
}

\begin{abstract}
Mexico's addition to the list of Designated Countries of Origin (DCO) i.e. safe countries in light of extreme human rights violations and government corruption raises many questions. Using government data obtained through the Access to Information Act, this qualitative study examines the DCO policy and safe country designation process and applies the country designation criteria to the case of Mexico. Through government discourse, the securitization of migration and the construct of the 'criminal' refugee claimant have become normalized, leading to exclusionary immigration legislation. While questioning whether or not Mexico belongs on the DCO list, this study reveals the unjustifiable discrimination contained in Canadian refugee policy, specifically the Protecting Canada's Immigration System Act (Bill C-31).
\end{abstract}

Key words: designated countries of origin (DCO), Mexico, securitization, refugee, asylum-seeker 


\section{ACKNOWLEDGEMENTS}

Many thanks to the supervisor of this study, Dr. Henry Parada, and the second reader, Dr. Dawn Onishenko, for their insightful feedback and invaluable advice.

I would also like to thank my friends and family for their continued support and encouragement throughout this process.

Finally, to David, mi amor, for your love and care, I couldn't have done this without you. 


\section{TABLE OF CONTENTS}

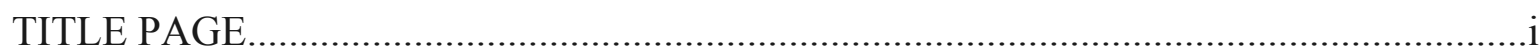

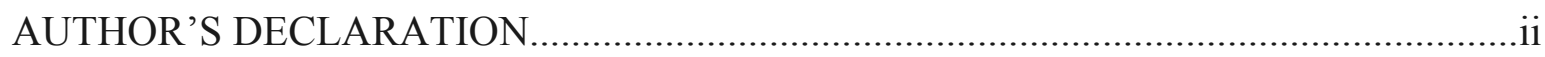

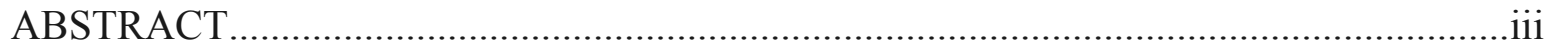

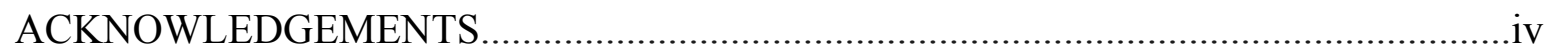

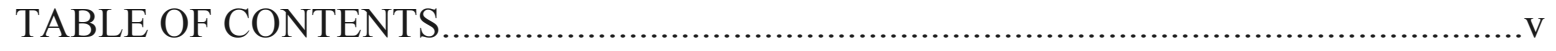

LIST OF ABBREVIATIONS............................................................................. vii

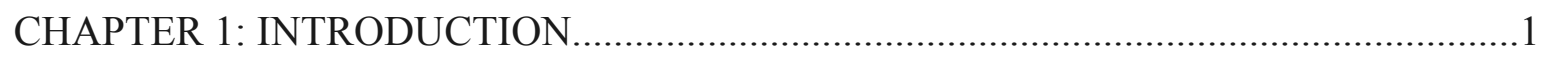

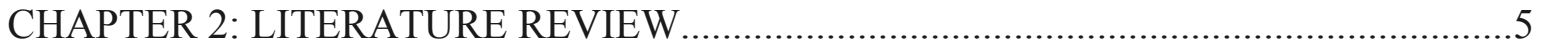

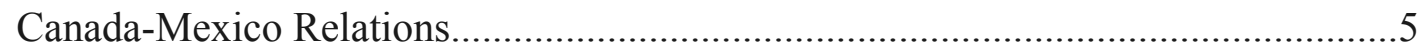

Securitization and Border Security................................................................. 7

The Definition of Refugee............................................................................

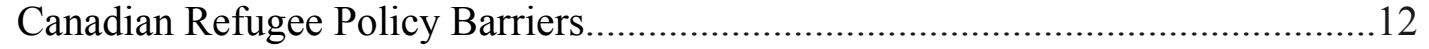

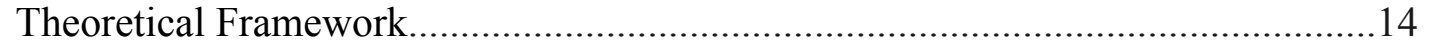

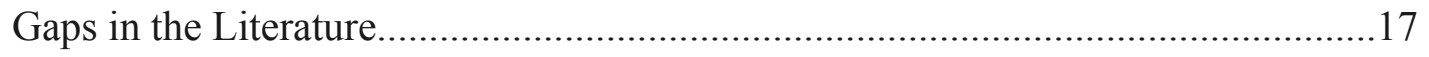

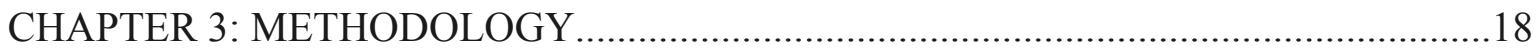

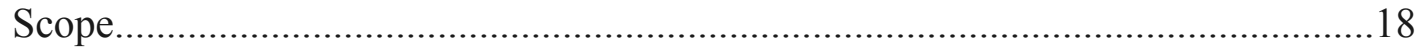

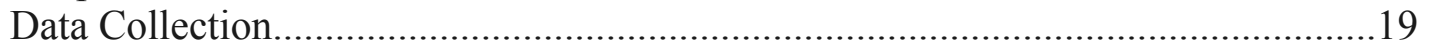

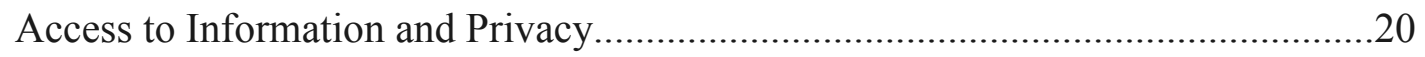

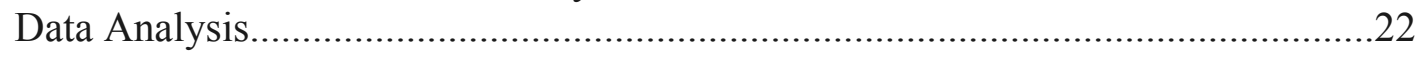

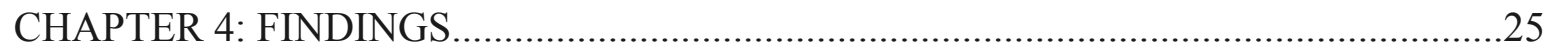

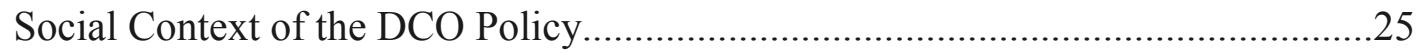

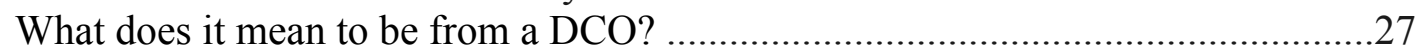

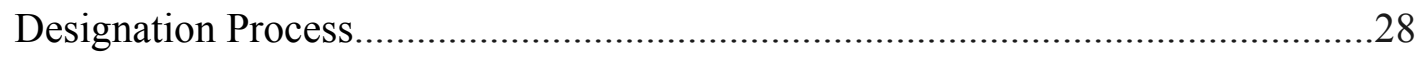

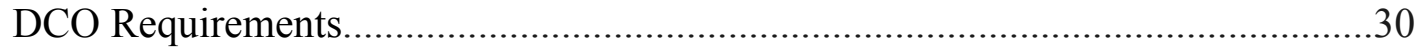

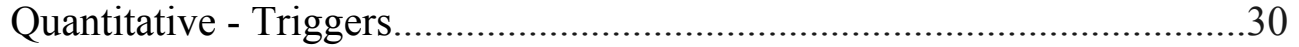

Qualitative - Country Review............................................................. 31

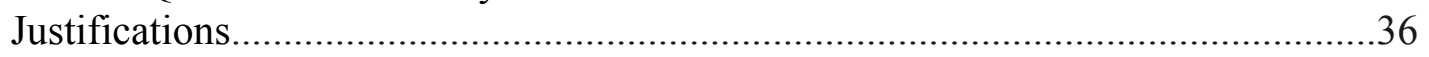

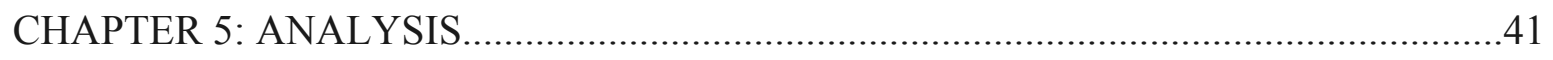

DCO Criteria

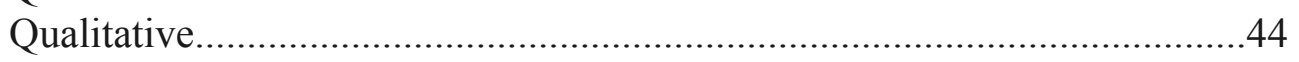

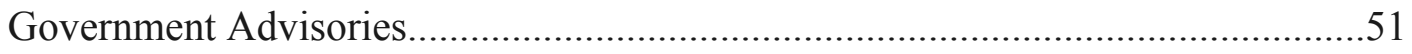

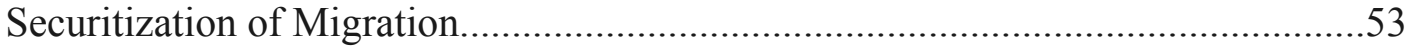

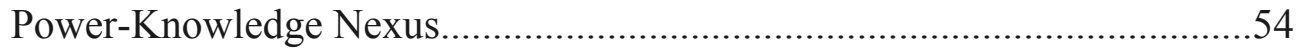

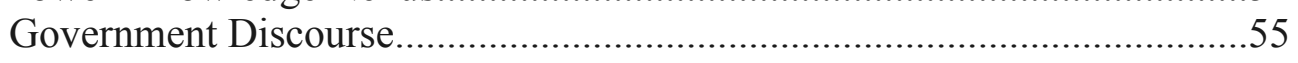




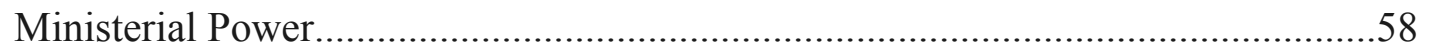

CHAPTER 6: CONCLUSIONS AND RECOMMENDATIONS...................................61

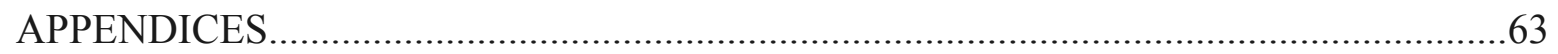

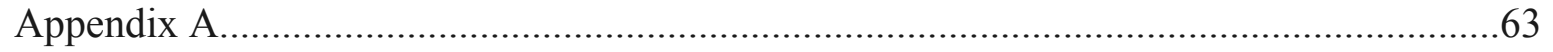

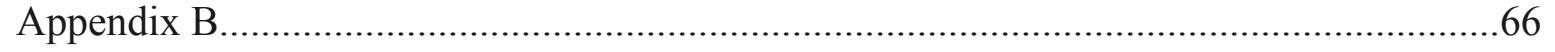

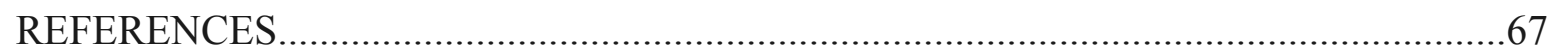




\section{LIST OF ABBREVIATIONS}

\begin{tabular}{|c|c|}
\hline $\mathrm{BOC}$ & Basis of Claim \\
\hline BRRA & Balanced Refugee Reform Act \\
\hline CAT & Convention Against Torture \\
\hline CBSA & Canadian Border Services Agency \\
\hline CCSPJP & $\begin{array}{l}\text { Consejo Ciudadano para la Seguridad Pública y la Justicia Penal (Civic } \\
\text { Council for Public Security and Criminal Justice) }\end{array}$ \\
\hline CEDAW & $\begin{array}{l}\text { Convention on the Elimination of All Forms of Discrimination Against } \\
\text { Women }\end{array}$ \\
\hline CIC & Citizenship and Immigration Canada \\
\hline $\mathrm{CRC}$ & Convention on the Rights of the Child \\
\hline DCO & Designated Country of Origin \\
\hline DFATD & Department of Foreign Affairs, Trade, and Development \\
\hline ICCPR & International Covenant on Civil and Political Rights \\
\hline ICERD & International Convention to Eliminate all forms of Racial Discrimination \\
\hline INEGI & $\begin{array}{l}\text { Instituto Nacional de Estadística y Geografía (National Institute of Statistics } \\
\text { and Geography) }\end{array}$ \\
\hline IRB & Immigration and Refugee Board \\
\hline IRPA & Immigration and Refugee Protection Act \\
\hline MACAD & Monitoring, Analysis, and Country Assessment Division \\
\hline NAFTA & North American Free Trade Agreement \\
\hline PAN & Partido Acción Nacional (National Action Party) \\
\hline PCISA & Protecting Canada's Immigration System Act \\
\hline PRD & Partido de la Revolución Democrática (Democratic Revolution Party) \\
\hline PRI & Partido Revolucionario Institucional (Institutional Revolutionary Party) \\
\hline PRRA & Pre-Removal Risk Assessment \\
\hline RAB & Refugee Affairs Branch \\
\hline RAD & Refugee Appeal Division \\
\hline SEGOB & Secretaría de Gobernación (Interior Ministry) \\
\hline SNSP & Sistema Nacional de Seguridad Pública (National Public Security System) \\
\hline
\end{tabular}




\section{CHAPTER 1: INTRODUCTION}

Refugees have fled from Mexico to Canada for countless years, with significant numbers seeking asylum for a variety of different reasons, including claims of political persecution, government corruption, domestic abuse, and sexual orientation (Neve, 2008). Some have been credible and made well-founded claims, while others have not. Some have been accepted, but most have been rejected (Immigration and Refugee Board [IRB] Refugee Status Determinations, 1989-2011). In 2009, over 9,000 Mexicans filed for refugee status in Canada, representing $42 \%$ of all refugee claimants, a drastic increase from less than 5\% of claims ten years before (Citizenship and Immigration Canada [CIC], 2012). Few of these claimants, however, were ever approved to become permanent residents of Canada (Massey \& Brown, 2011).

Since 2006, when the administration of Felipe Calderón was elected in Mexico and launched a military operation against the country's drug cartels, many Mexican civilians have become caught in the crossfire of narco-traffickers who pay off the police and the government to buy control of entire regions. In most of the Mexican refugee cases, claimants are fleeing extortion, including threats of violence from criminal gangs linked to narco-trafficking (Day, 2009). Instead of accepting these legitimate refugees fleeing from violence and corruption, Canada's response was to securitize the border and enact several policy barriers to curb the number of refugees entering Canada from Mexico. These policies include the Safe Third Country Agreement, the visa requirement announced in 2009, and most recently the addition of Mexico to the list of Designated Countries of Origin i.e. safe countries. The high numbers of refugee claimants abruptly changed with the imposition of the visitor visa in 2009, which resulted in the number of refugee claims from Mexico dropping from 9,322 in 2009 to just 736 in 2011 (IRB, 2011). 
In 2004, of the 2,684 Mexican refugee claims finalized by Canada's IRB, only $25 \%$ were accepted (Mueller, 2005). This may be due to the perception that Mexico was not a "refugee-producing country," and that asylum seekers from the country were primarily economic refugees and those whose claims were based on sexual orientation and domestic violence (George, 2008). Nevertheless, in 2009, a peak time of violence and corruption in Mexico's ongoing war, out of the 9,322 refugee claims made, only 515 were accepted, a rate of $8 \%($ IRB, 2011). As a signatory to The 1951 Convention relating to the Status of Refugees, Canada allows a number of refugees to enter the country every year. There is also a provision for inland applications for refugee status for those whose lives are in danger, the applications of which are assessed by the Immigration and Refugee Board (George, 2008). However, the burden of proof lies on the applicant who does often not hold sufficient evidence to prove threat of life, especially when that threat comes from nonrecognized organizations such as drug cartels and inter-government corruption.

Human rights violations, such as intimidation, torture, forced disappearances, extrajudicial killings, and the use of excessive force are widely reported, but the large majority of these abuses go unpunished (Molzahn, Rodriguez, \& Shirk, 2013; Tuckman, 2012; Zúñiga, 2013). In fact, the Mexican government considers such violations exceptional and remains without effective measures to prevent, investigate, or punish serious human rights violations committed by police and criminal organizations (Gilbert, 2013a; Amnesty International, 2012). It is in the absence of state protection that violence directed at individuals becomes a human rights violation. In that sense, the refugee crisis in Mexico is a crisis of the general mistrust of the Mexican state and its capacity to safeguard civilians' fundamental human rights (Gilbert, 2013a). The majority of these asylum applications from Mexico are being systematically rejected in the United States and Canada 
on the basis that victims of drug wars are not seen as "refugees" and on the premise that the Mexican state is able to protect its citizens (Wright, 2012).

The most recent act of securitization by the Canadian government against Mexican refugees was the addition of Mexico to the list of Designated Countries of Origin (DCO) also known as "safe" countries. According to Citizenship and Immigration Canada (CIC), Designated Countries of Origin "will include countries that do not normally produce refugees, but do respect human rights and offer state protection" (CIC, 2013a). While the Minister claims that the new refugee reforms will not limit access to refugee applicants from "safe countries," rhetorical distortions have already criminalized Mexicans as "abusers" of the Canadian refugee system (Gilbert, 2013a, p. 154). Through this construct of alleged abuse, Gilbert (2013a) argues that politicians have reduced a multifaceted migration condition to "bogus" claims, trivializing human rights and failing to appreciate Mexico's “complex political reality" (p. 154). Mexico is still a country in the throes of a human rights crisis and Canada is no longer recognizing it to be a genuine source of refugees.

There are several personal experiences which have led to the exploration of this topic. The first was living in the northern city of Chihuahua, Mexico, a city ravaged by the ongoing drug war. I lived and worked in the city in 2010 and 2011, a peak time of narcoviolence. It was distressing to see the hometown of my husband, a once safe and vibrant community, overrun with violence and corruption. The experience that really cemented my desire to investigate this issue was when a member of my family became one of the innocent victims of narco-violence. These experiences of living in fear and constant violence, along with the legal and political frustrations involved, made me reflect on my own position and the position of the Canadian government. I do not understand why the 
Canadian government has turned its back on tens of thousands of displaced Mexican citizens, instead going to extensive measures to keep them out of Canada.

This leads to the research question: Does Mexico belong on the list of Designated Countries of Origin? The purpose of this qualitative study is to examine the criteria for designation and apply it to the case of Mexico while trying to figure out why such a country was declared safe. In addition to this argument, the discriminatory DCO policy established in Bill C-31 Protecting Canada's Immigration System Act (PCISA) and the criminalization of Mexican refugees in government discourse are explored.

Using government data, combined with statistics and country reports from Mexico, this qualitative study uses content analysis as method of inquiry. The concept of securitization with a critical anti-oppressive framework is the theoretical perspectives that led the research and data analysis. By applying a critical anti-oppressive lens to analyze the construct of the Mexican asylum-seeker within the neo-liberal discourse of 'criminal' refugees, I will demonstrate that through government discourse, this construct of refugees being defined as a security threat to Canadian citizens has led to the creation of exclusionary immigration legislation. Although answering this question may not solve the social problem itself, I believe that the answer will reveal some of the unilateral policy measures Canada imposes on Mexican refugees in the hopes that it will influence other academics and perhaps even policymakers to consider the reasons behind recent changes to immigration policy and practice. 


\section{CHAPTER 2: LITERATURE REVIEW}

The following literature review is centered on the immigration relationship between Mexico and Canada in the last decade (i.e. 2003-2013), specifically Canada's construction of Mexican refugees as a security threat. Articles and book chapters included in this review are all scholarly works published on this topic, along with CIC and IRB statistics, which examine the major policy debates and issues regarding this relationship. This literature review was assembled from articles found through various university library servers including University of Toronto, University of British Columbia, York University, and most prominently, the Ryerson University Library and Archives, using different combinations of the keywords: Canada, Mexico, migration, refugee, border, security, narco-violence, drug-violence, bogus refugee, criminal refugee, and securitization. Based on a critical reading of the most relevant articles, common themes were selected which resulted in the research question. The prominent themes explored are: Mexico-Canada relations, securitization and border security, the definition of refugee and whether or not it incorporates those fleeing drug violence, and Canadian immigration policy barriers to Mexican refugees including the Safe Third Country, visa requirement, and Mexico's recent addition to the Safe Country List.

\section{Canada-Mexico Relations}

While most articles regarding Mexican refugees in Canada make brief mention of the economically driven relationship between the two countries (Díez, 2008; Gilbert, 2013ab; Ibrahim, 2005; Massey \& Brown, 2011; Neve, 2008; Russo, 2008), there are only few which make the bilateral association their main focus (Abizaid, 2004; Santa-Cruz, 2012). Santa-Cruz (2012) describes the nature of the Canadian-Mexican relationship throughout history as feeble, exemplifying the diplomatic and economically based 
relationship between Canada and Mexico with many instances of cooperation such as the Security and Prosperity Partnership of North America. Since the onset of NAFTA, Abizaid (2004) argues that Canada and Mexico have developed a "dynamic and mature relationship" covering many levels of government but that the bilateral relationship between Mexico and Canada is far from realizing its full potential (p. 2).

In many of the examples given by Santa-Cruz (2012) and Abizaid (2004), it is evident that bilateral partnerships and agreements have been dominated by a security agenda defined by the United States. Santa-Cruz (2012) speaks to Canada and Mexico's shared values, "like-mindedness", and similar geopolitical situation but concludes that no meaningful community of interests or shared identity can be said to exist (p. 143). SantaCruz (2012) presumes that the two countries are bound to remain distant neighbours for a long time. Both Abizaid (2004) and Santa-Cruz (2012) provide an extremely detailed and helpful history of bilateral relations but negate to include one important factor of contention between the two countries - refugees. No mention is made of the various immigration policy restrictions imposed on Mexican refugees. Despite this glaring oversight, SantaCruz's summary of Canada-Mexico political and economic relations remains one of the most comprehensive and current.

Despite a long history of diplomatic relations and economic partnerships, the literature surrounding Canada-Mexico relations pales in comparison to the wealth of information regarding Mexico's relationship with the United States. However, in many cases, the research concerning the United States and Mexico provides useful for refugee policy comparison and recommendations. 


\section{Securitization and Border Security}

When analyzing immigration and refugee policy, securitization discourse is crucial. The political practice of securitization takes place when a subject or group of subjects, such as refugees, are constructed as an existential security threat to the general public (Buzan, Wæver, \& Wilde, 1998). Many authors (Díez, 2008; Gilbert, 2013a; Harville, 2012; Ibrahim, 2005; Neve, 2008; Russo, 2008) mention security, especially with reference to the Mexico-U.S. border, but few (Gilbert, 2013b; Ibrahim, 2005) discuss the construction of the Mexican refugee as a security threat to Canada, a common thread in government discourse today.

Ibrahim (2005) describes the new discourse of the securitization of migration, which both Ibrahim and Gilbert (2013b) agree has informed government policy in Canada resulting in discriminatory immigration legislation. Ibrahim (2005) argues that through security discourse and subsequent practice, Canada has "transformed migrants into agents which threaten human security" (p. 164). Gilbert (2013b) applies the theories presented in Ibrahim (2005) to the case of Mexican refugees in Canada, examining the dominant media discourse which encodes Mexicans as illegal, criminal and fraudulent Others. Both authors agree that, "such discourses reveal overt and inferential forms of racism" and challenge the self-proclaimed tolerance of a multicultural Canada (Gilbert, 2013b, p. 827).

On the topic of border security, Díez (2008) discusses the notion of a North American trilateral agreement on security and notes that while several steps have been taken by the three countries to strengthen cooperation, it appears that the establishment of an international regime that would resemble anything close to a security perimeter is far from happening. A trilateral security agreement might prove impossible as Díez (2008) notes that Mexico has traditionally looked inward on matters of security and has a different 
conception of security than Canada or the United States. In accordance with Díez (2008), Neve (2008) states that although NAFTA has opened up the borders for economic traffic, it is much more reticent in allowing people to move across them with the same degree of freedom.

Gilbert (2013a) also speaks of Mexico-U.S. trade relations, which despite being very successful, are constantly strained by immigration issues specifically related to cross-border mobility and the significant "unauthorized" Mexican population living north of the border (p. 143). Security has, of course, long been a very visible and active presence along the U.S.-Mexico border, but it is now becoming a major component of the Canadian frontier as well (Neve, 2008). Canada's pursuit of further security measures against Mexico represents the imposition of the priorities of the United States (Díez, 2008). Gilbert (2013a) argues that Canada's sudden visa requirement for Mexicans in 2009 generated a similar anxiety about Canadian border governance politics that have now extended from the border itself into the visa offices in Mexico.

Neve (2008) discusses the security of refugees through human rights protection based on theories of human security and concludes that Canada and the United States need to commit to a North American human rights agenda with strong provisions about migration, including the protection of refugees. However, neither Díez (2008) nor Neve (2008) discuss the uneven number of refugees moving from Mexico to the United States and Canada and the different security concerns this entails for the two borders. In these reviews of the securitization of North America, border security seems to be separated from state sovereignty and is not discussed as a country-specific issue, leaving a gap in the literature. 
Harville (2012), speaking specifically of those fleeing drug violence, claims that the extension of refugee protection to the massive numbers of asylum seekers from Mexico would necessitate increased investment in the already overburdened asylum infrastructure, particularly along the U.S.-Mexico border. Nevertheless, as Harville (2012) explains, "such expenses would be a mere drop in the bucket compared to the exponential amounts of money spent by the American federal government on border security infrastructure," ( $p$. 182) including increased border patrol and customs agents, construction of the border wall, and expanded use of technology. Harville (2012), in accordance with Díez (2008) and Neve (2008), contends that these additional expenditures are not too great a sacrifice for the American or Canadian government to make given the human rights at stake.

In seeming opposition to the objective of individual refugee safety and security, is Collacot (2010) who expresses his belief that the true refugees are those overseas, not those in Canada's own backyard. Collacott (2010) argues that Canada's refugee determination system is open to widespread abuse, unfair to genuine refugees waiting to come to Canada, extremely costly, and constrained by domestic and international legal obligations that are ill-fitted to current realities. Collacott's focus on national sovereignty over human security and his correlation of Mexican refugees and "bogus" claimants are unfortunately characteristic of the current Canadian government discourse which uses policy as means to securitize the borders and keep Mexicans from claiming refugee status.

\section{The Definition of Refugee}

A key theme evident throughout the literature regarding Mexican refugees in

Canada is the definition of the term refugee and specifically whether or not it includes those fleeing from drug violence. Most authors (Buchanan, 2010; Collacott, 2010; Gilbert, 2013a, 2013b; Harville, 2012; Poulton, 2010; Wright, 2012) refer to the UN Convention definition 
of refugee, which is arguably outdated in regards to this dilemma, leaving the question of who qualifies as a refugee open for interpretation. As stated by Buchanan (2010), Mexican asylum-seekers fleeing from drug violence do qualify for refugee status as defined by the 1967 Protocol. In agreement with Gilbert (2013ab), Harville (2012), Poulton (2010), and Wright (2012), Buchanan (2010) argues that the key component of the refugee definition, the requirement of a 'well-founded fear of being persecuted,' is met by asylum-seekers from Mexico seeking refugee status based on the drug-related violence occurring in their country of origin despite the fact that much of the drug-related violence in Mexico is generalized violence used to intimidate or retaliate against Mexican citizens. Buchanan (2010) goes on further to argue that persecution of one's family or friends, for example, may be sufficient to establish that the applicant has an objective fear that he or she will also be persecuted.

Buchanan (2010) and Harville's (2012) views, although based on an American legal perspective, highlight the values that are entrenched in the UN Convention. Harville (2012) argues that by withholding asylum protection to the vast majority of Mexican asylum seekers, the United States is not fulfilling its nonrefoulement obligations under international treaties and domestic law, a statement widely applicable to Canadian immigration policy as well. Unlike most of the Canadian literature, Buchanan (2010) and Harville (2012) address the substantial nexus between the Mexican government and the drug trafficking organizations, thus rendering the state incapable of protecting citizens fleeing drug-related violence, a fact that asylum adjudicators in the U.S. and Canada have largely ignored. Both of Gilbert's articles (2013a; 2013b), like Buchanan (2010) and Harville (2012), highlight the various challenges to the dominant understanding of refugee claimants as persons suffering persecution and being unable to secure any form of protection due to 
the nature of narco-violence. Gilbert (2013a) convincingly argues that by insisting human rights violations are exceptional or letting them go unanswered and affirming that the violence generated by the drug war is concentrated in certain areas, the Mexican state has constructed citizens needing and seeking protection outside of the conventional definition of the "asylum-seeker" (p. 153).

The common belief that drug violence is internal to the drug trade, i.e., perpetrated by criminals against criminals and therefore not affecting law-abiding citizens, stems from the government's discussion of drug violence which normalizes "a blame-the-victim story" and is a prevalent discourse throughout the literature (Buchanan, 2010; Gilbert 2013a; Harville, 2012; Wright 2012). Wright (2012), whose research is focused on violence among Mexico-U.S. border towns, explains that a key component of this discourse is that the violence is not random but within the drug trade, and the general public, which is largely innocent of criminal activity, need not worry. The United States government, much like Canada, uses this reasoning to exclude those seeking asylum from drug-related violence. Collacott (2010) states that the UN Refugee Convention is out of date and goes so far as to suggest that Canada should withdraw its accession to the Convention. In stark opposition to most others (Buchanan, 2010; Gilbert, 2013a, 2013b; Harville, 2012; Poulton, 2010; Wright, 2012), Collacott (2010) argues that with regard to Mexican claimants, fleeing criminal violence is not equivalent to suffering from persecution as stipulated by the Convention. However, Poulton (2010) fires back with numerous examples of persecution that meet the definition. Collacott (2010) states that, "if this kind of problem were accepted as grounds for being granted asylum, there would undoubtedly be millions more around the world entitled to come here as refugees" (p. 111). This alarmist viewpoint characteristic of 
the refugee discourse of the current government which labels many Mexican refugees as 'bogus' and 'fraudulent' is fortunately countered by the majority of literature in the field.

The term refugee is also influenced by the media's discourse of those seeking asylum. The only author who examines the media's impact on Mexican refugees in Canada is Gilbert (2013b), who argues that local Canadian media depicts Mexican refugees as criminal Others that exploit the deficiencies of the Canadian refugee system. In many cases, as Gilbert (2013b) demonstrates, the media argues that "these Mexicans are not refugees by definition" (p. 835). While most of the authors argue for the right of each refugee's individual claim to be heard, some academics, such as Collacott (2010), still hold the narrow-sighted and generalizing view that the 'real' refugees must be filtered out from the 'false' masses by implementing exclusionary policies. This is a dangerous view for the rights protection of all refugees and must be carefully interpreted.

\section{Canadian Refugee Policy Barriers}

There are three major policy barriers for refugees claimants from Mexico: the Safe Third Country Agreement, the visa requirement, and the recent addition of Mexico to the Safe Country List. These three policies, as utilized by the Canadian government, make it nearly impossible for Mexicans to seek asylum in Canada, let alone be accepted as genuine refugees. The literature commonly looks at these three policies separately, given their timeframe.

The Safe Third Country Agreement, signed by the U.S. and Mexico shortly after 9/11, represents the start of a security-related focus on refugees from Mexico. Neve (2008) explains that under this agreement the bulk of refugee claimants who pass through the United States on their way to Canada will no longer be able to access Canada's refugee determination system and will instead be required to make their claims for asylum in the 
United States (p. 81), an exercise which has recently been held as a violation of international human rights law (Poulton, 2010).

However, not everyone sees the potential danger in applying such course of action. Collacott (2010), for example, argues that Canada must apply the Safe Third Country principle more robustly in order to stop those who are asylum shopping. Collacott (2010) states that refugees traveling through one country to reach another are "not primarily concerned with reaching safety but rather with being allowed to seek asylum and remain permanently in countries where there are generous benefits and high rates of acceptance" (p. 114). Poulton (2010) vehemently opposes Collacott's claims by stating that the vetting of who is and who is not a genuine refugee must be left to an impartial tribunal, not the political process of determining a safe third country. The consequence of Collacott's proposal for a more robust safe third country provision in our current law, according to Poulton (2010), is that Canada would act in violation of international human rights law and be subject to protracted litigation and international criticism.

As Neve (2008) points out, in a now-dated article, there were many refugees who came to Canada, surpassing the Safe Third Country rule, and with "some ease in doing so since there is no visa requirement for Mexicans wishing to travel to Canada, meaning that those with the means to fly are fairly readily able to get here, and thus avoid having to cross the United States by land" (p. 80). However, in July 2009, the Harper government imposed a visa requirement on all Mexicans traveling to Canada, legitimizing its decision by referring to the rising number of requests for refugee status from Mexico. Gilbert (2013a) examines the discourse used by Conservative politicians to rationalize this requirement and argues that the imposition of the visa that is intended to stop refugee claimants from Mexico also serves to criminalize them using official rhetoric and prejudicial language ( $\mathrm{p}$. 
139). This discourse implies the bilateral denial of the human rights crisis created by narco-violence and corruption (Buchanan, 2010; Gilbert 2013a; Wright, 2012).

On 29 June 2010, Jason Kenney's Balanced Refugee Reform Act (Bill C-11) gave the Minister the power to develop a list of Designated Countries of Origin (DCO) or "safe countries" defined as countries that do not normally produce refugees but do respect human rights and offer state protection (CIC, 2013a). Many critics (Gilbert 2013b; Neve, 2008; Wright 2012) declared that designating Mexico a 'safe' country would be denying the human rights crisis created by the violent drug wars and the erosion of the power of the state to protect and while eliminating the need for the visa, was likely to prove discriminatory towards many Mexicans. Despite various condemnations, Mexico was added to the DCO list on February 15, 2013. Gilbert (2013a) argues that the designation of Mexico as a 'safe country' is based on a complementary political rationality that Mexicans are in no need of protection despite high levels of violence and human rights abuse by the state. The literature regarding this recent policy reform is scarce, outside of newspaper articles, and lacking in the available literature is a discussion of which facts determine these 'safe' assessments, specifically for Mexico.

\section{Theoretical Framework}

Two main theoretical perspectives will inform the data collection and analysis in order to address the research question. What follows is a brief description of each theory and how it will be used to guide the research and data analysis.

\section{Securitization}

The Canadian government has framed the influx of Mexicans seeking asylum in Canada as a matter of national security rather than a human-rights crisis. This is an act of securitization, a concept of political practice connected with the Copenhagen School, in 
which a subject or group of subjects, such as refugees, are constructed as an existential security threat to the general public or audience (Buzan, Wæver, \& Wilde, 1998). Securitization is largely seen as a combination of social constructivism and classical political realism in its approach to international security (Buzan et al., 1998). Securitization, according to Buzan et al. (1998), is a speech act that dramatizes and presents an issue as of supreme importance. By claiming an issue is a matter of security, an agent "claims a need for and a right to treat it by extraordinary means" (Buzan et al., 1998, p. 25). The production of a truth, or the creation of knowledge through a discourse, is an exercise of power and thus the securitization of migration can be examined as a discourse through which relations of power are exercised (Ibrahim, 2005). For the securitizing act to be successful, it must be accepted by the audience. This is often accomplished through the dehumanization of refugees prevalent in government discourse, which labels entire populations of refugees as "bogus" individuals (Betts 2010; Esses, Veenvliet, \& Hodson, 2008). Using the theory of securitization as a theoretical framework, this study explores how through Canadian government discourse, the construction of refugees as a security threat has led to the creation of new exclusionary immigration legislation.

\section{Critical Anti-Oppressive Framework}

The concept of anti-oppression is prevalent in the fields of social work and education and more recently in political research and policy. Anti-oppressive theory and practice frameworks share values of equity, inclusion, empowerment, and community (Campbell, 2003). In practice, the anti-oppressive framework has been informed by ideas that emanate from critical theory, which challenges taken-for-granted assumptions about social order (Dalrymple \& Burke, 2006). Enforced exclusion from desirable opportunities and experiences is the demarcation of oppression. Therefore, the definition of anti- 
oppression is inclusion. The dominant narrative about the need to control the alleged abuse of the Canadian refugee system influences the determination process of Mexican refugee claimants and serves as the argument for the passage of exclusionary policies. I will use the critical anti-oppressive framework to analyze the construct of the Mexican asylum-seeker within the neo-liberal discourse around criminalized refugee claimants.

It must be recognized that the structure of oppression faced by Mexican refugee claimants is not limited to the label of migrant, but rather crosses multiple boundaries of identity. People have many social identities including gender, race, ethnicity, citizenship, sexuality, class, which are influenced by historical, socio-cultural, and political factors (Sakamoto \& Pitner, 2005, p. 442). How individuals position themselves within these various identity groups affects the perceptions of both the self and others. According to Sakamoto and Pitner (2005), these multiple identities also accompany statuses so one may be privileged by some identities, yet oppressed by others. For example, a male may be privileged due to his gender but oppressed because of his immigration status. A study by Bastia (2014) shows that the theories of intersectionality have greatly contributed to mapping the interconnected and constitutive nature of multiple forms of oppression and privilege in the process of migration. In the case of Mexican refugee claimants in Canada, issues of intersectionality interact as a process affecting these refugees, who are already considered racialized. As Squires (2008) states, distinct forms of oppression shape, and are shaped by, one another, and a failure to recognize this results in both "simplistic analyses and ill-conceived policy interventions" (p. 55). Therefore, it is increasingly important to acknowledge theories of intersectionality when employing anti-oppressive practice in order to address the complex ways in which these identities intersect and construct the status of an individual. 


\section{Gaps in the Literature}

Mexican migration to the United States is one of the largest and most studied population movements in history. While considerable attention has been paid to this vast migration nexus by international academics and policymakers, Mexican migration to Canada remains relatively under the radar. Furthermore, there is relatively little research regarding the addition of Mexico to the list of Designated Countries of Origin due mainly to its recent occurrence and the vague details available as to why this decision was made. The Mexican refugee issue is not widely researched in a Canadian context, possibly due to its more current nature and the relatively small numbers of claims accepted. More focus is needed on the qualifications for a 'safe' country as well as more individual case studies, highlighting the different types of refugee claims from Mexico. In general, Mexican refugee claims are thought of as a single entity and in order to answer some of the many questions arising from this issue, more attention is needed on individual cases.

Canada's rejection of Mexican asylum-seekers is fraught with dilemmas and unanswered questions. This research, along with numerous facts and figures, leads to the research question: Does Mexico belong on the list of Designated Countries of Origin? 


\section{CHAPTER 3: METHODOLOGY}

\section{Scope}

This study is an exploratory qualitative study using content analysis as method of inquiry. The central question this study addresses is: Does Mexico belong on the list of Designated Countries of Origin? In answering this question, the study will explore the issues of:

a) the Designated Countries of Origin (DCO) policy as established in the PCISA

b) the criteria for designation and whether or not Mexico complies

c) the criminalization of Mexican refugees in government discourse

Due to the lack of previous research on this topic and therefore the lack of quantifiable data, a qualitative approach will best suit the desired research strategy. In order to find the answer to this question, the data must come from the government officials who decided the criteria for this ruling. A content analysis of communications between members of the Refugee Affairs Branch (RAB) of the CIC was conducted. According to Trimble and Treiberg (2011), content analysis is used to analyze the message characteristics in any form of communication through which researchers can methodically account for the content in texts. Content analysis was chosen as the methodology for this study because it allows the researcher to answer questions about the ways in which political issues, assumptions, and norms are conveyed through government discourse. An observation about the securitization of immigration in Canada may be formed from being exposed to media and government discourse but without evidence to back up this observation, it is merely an assumption. Content analysis provides that evidence in a systematic, reliable, and rigorous manner (Trimble \& Treiberg, 2011). When using government data, as this study does, content analysis allows measurement of many features of political communication, including what 
Trimble \& Treiberg (2011) refer to as structural and substantive features. For the purposes of this study, the focus is on the substantive features, meaning the words, themes, ideas, or symbols in a text, and incorporates both the manifest and latent content of the texts in the data analysis.

This study focuses solely on Mexico and Canada's refugee determination process. It is also limited to government statistics and data and purposefully leaves out the impact of media on the proliferation of 'bogus' refugee discourse and the criminalization of Mexican claimants.

\section{Data Collection}

The data was obtained from the Canadian government, specifically Citizenship and Immigration Canada, using the Access to Information Act to request any existing documentation related to the determination of a Designated Country of Origin or 'safe country'. In March 2014, the following request was submitted to three departments, Citizenship and Immigration Canada (CIC), Foreign Affairs, Trade and Development (DFATD), and Canadian Border Services Agency (CBSA):

Any correspondence, memos, reports, records of meetings/minutes of meetings, regarding Mexico as a Designated Country of Origin (safe country) from 2009 to the present, especially around February 15, 2013 when Mexico was added to the list of DCOs. Minister's speaking notes regarding Mexico's addition to the list of DCOs. Any briefing notes regarding Mexico as a Designated Country of Origin/safe country Any minutes of meetings with ambassador of Mexico in regards to Mexico as a Designated Country of Origin/safe country (M. Baker, personal communication, March 24, 2014)

However, due to the large scope of the search and the time constraint of this study, I was given the option to 'piggy-back' other similar requests that were near completion. The requests I was attached to, which produced over 1000 pages of information, are as follows: 
All existing documentation, including but not limited to emails, communications, reports, briefing notes, analyses, memos and communications relating to the designation, or determination of a designation, of a country (designated countries of origin (DCO) or 'Safe country' Feb 1May 312012 (S. Clemenhagen, personal communication, March 28, 2014)

From January 1, 2010 to November 5, 2013, All internal and external correspondence (emails, letters, memoranda, surveys, queries, paperwork, etc) relating to the drafting or decision-making relating to each of "Designated Country of Origin Review" for Croatia, Hungary, and Mexico pursuant to s. 109.1 of the Immigration and Refugee Protection Act (S. Clemenhagen, personal communication, April 7, 2014)

While these requests were not specific to Mexico, they provided data to support the claim that Mexico does not belong on the list of DCOs.

In addition to the information supplied by the Canadian government, statistical evidence from the Mexican government (available online) such as the rates of homicide, violent crime, kidnappings, and forced disappearances was used. The trustworthiness of the data supplied by the Mexican government is an issue due to the extremely high levels of police corruption and the number of crimes committed that go unreported. Nevertheless, the information released by the government of Mexico, regardless of how much lower the statistics are than in reality, still suffices to prove whether Mexico meets the criteria to be listed as a 'safe' country. Issues of under-reporting and police corruption will be explored in order to produce a legitimate study (Bowden, 2010; Molzahn, Rodriguez, \& Shirk, 2013; Zúñiga, 2013).

\section{Access to Information and Privacy}

The Access to Information and Privacy (ATIP) Acts give Canadian citizens, permanent residents, or any person or corporation present in Canada a right to access information that is contained in government records. The ATIP Online Request tool proved key in obtaining information about the Designated Country of Origin policy and the criteria 
for designation. While the list of DCOs and the quantitative criteria is made available to the public, the extensive criteria for country reviews as well as the end product of the country reviews themselves are not. CIC argues that there is no intention to make the reviews public given the possible release of sensitive information and potential impacts on bilateral relations leaving unclassified and less sensitive content to be released through Access to Information Requests (U. Chauhan, internal communication, March 29, 2012b). The visa policy framework document established in 2005 specifies that Country reports are classified Secret and that this information will never be made public, even through Access to Information Requests (D. Cashaback, internal communication, May 8, 2012). Due to the sources used, including information from security partners and third countries, and possible impacts on Canada's bilateral relations arising from the analysis and recommendations, there are several grounds on which the Canadian government has recommended the reports be excluded from release (D. Cashaback, internal communication, May 8, 2012). This means that any information and recommendations provided to the Minister before designating a country will never be made available to the public, leaving the question of why Mexico was added to the list of DCOs virtually impossible to answer. In addition to Country Reviews, Question Period Notes regarding refugee reform and the designated country of origin policy are also withheld. Whenever a country is mentioned in a document, briefing notes, email, or any other communication, the name of the country is blanked out, as well as any clues that may give the nation away. This makes evaluating how countries are designated or even selected quite difficult and keeps the justification for designation of a country by the Minister classified. The lack of transparency of this process brings up many concerns about the impartiality and objectivity of these designations, and will be further explored. 


\section{Data Analysis}

In order to assemble the data needed to answer the research question, a content analysis table was used (see Coding Table 1, Appendix A, p. 63). This content analysis table helped to isolate the parts of the information supplied by the government that were relevant to the research question. This table was used during the open coding process, in order to establish the prominent themes in the data.

After sufficient open coding was completed, the texts which included applicable data were reorganized by theme, subtheme, condensed meaning, and content, both manifest and latent (see Coding Table 2, Appendix A, p. 65). Examples of how this table was used to organize the data follows below:

\begin{tabular}{|c|c|c|c|c|c|}
\hline ID & Theme & Subtheme & $\begin{array}{l}\text { Manifest } \\
\text { Content }\end{array}$ & $\begin{array}{l}\text { Latent } \\
\text { Content }\end{array}$ & Quote \\
\hline $\begin{array}{l}\text { Ge6 } \\
12 / 02\end{array}$ & $\begin{array}{l}\text { DCO } \\
\text { Country } \\
\text { Triage } \\
\text { List }\end{array}$ & $\begin{array}{l}\text { country } \\
\text { review } \\
\text { priority }\end{array}$ & $\begin{array}{l}\text { countries } \\
\text { are } \\
\text { prioritized } \\
\text { based on } \\
\text { claim value }\end{array}$ & $\begin{array}{l}\text { the larger } \\
\text { the number } \\
\text { of claims } \\
\text { from a } \\
\text { country, the } \\
\text { more of a } \\
\text { threat it } \\
\text { imposes }\end{array}$ & $\begin{array}{l}\text { "... the following country } \\
\text { assessments have already been } \\
\text { completed. These assessments } \\
\text { will need to be updated in time for } \\
\text { CIF. In addition to the completed } \\
\text { assessments, I have identified and } \\
\text { prioritized the following countries } \\
\text { for an assessment by CIF. Please } \\
\text { note that I did not include any } \\
\text { countries with a higher than } 25 \% \\
\text { acceptance rate and with less than } \\
30 \text { claims in the past year. } \\
\text { Countries have been prioritized } \\
\text { based on claim volume. We may } \\
\text { want to consider giving more } \\
\text { priority to some [WITHHELD] } \\
\text { countries, but can discuss later if } \\
\text { needed. It may be beneficial to } \\
\text { review the assessment priorities } \\
\text { on an ongoing basis. High } \\
\text { Priority: [WITHHELD]" }\end{array}$ \\
\hline $\begin{array}{l}\text { Ge47 } \\
12 / 03\end{array}$ & $\begin{array}{l}\text { DCO } \\
\text { Country } \\
\text { Review }\end{array}$ & $\begin{array}{l}\text { classificati } \\
\text { on of } \\
\text { DCO }\end{array}$ & $\begin{array}{l}\text { country } \\
\text { reviews will } \\
\text { not be made }\end{array}$ & $\begin{array}{l}\text { no country } \\
\text { review } \\
\text { information }\end{array}$ & $\begin{array}{l}\text { "There is no intention to make the } \\
\text { reviews public given the possible } \\
\text { release of sensitive information }\end{array}$ \\
\hline
\end{tabular}




\begin{tabular}{|c|c|c|c|c|c|}
\hline & & $\begin{array}{l}\text { country } \\
\text { reviews }\end{array}$ & public & $\begin{array}{l}\text { means no } \\
\text { way to } \\
\text { challenge } \\
\text { designations }\end{array}$ & $\begin{array}{l}\text { and potential impacts on bilateral } \\
\text { relations. Unclassified and less } \\
\text { sensitive content would be } \\
\text { released through Access to } \\
\text { Information Requests. The criteria } \\
\text { and indicators considered in a } \\
\text { possible designation could be } \\
\text { made publicly available. The list } \\
\text { of designated countries would } \\
\text { also be made public." }\end{array}$ \\
\hline $\begin{array}{l}\text { Ge81 } \\
12 / 02\end{array}$ & $\begin{array}{l}\text { DCO } \\
\text { Country } \\
\text { Review }\end{array}$ & $\begin{array}{l}\text { Panel of } \\
\text { Experts - } \\
\text { Simulation } \\
\text { s?? }\end{array}$ & $\begin{array}{l}\text { Minister } \\
\text { said } \\
\text { simulation } \\
\text { of panel of } \\
\text { experts was } \\
\text { run but it } \\
\text { was too } \\
\text { slow so it } \\
\text { was } \\
\text { removed }\end{array}$ & $\begin{array}{l}\text { Not true? } \\
\text { Minister } \\
\text { used this lie } \\
\text { to justify } \\
\text { minister's } \\
\text { designation } \\
\text { power in } \\
\text { lieu of a } \\
\text { panel of } \\
\text { experts }\end{array}$ & $\begin{array}{l}\text { "Apparently the minister said } \\
\text { something about running } \\
\text { simulations' for the Expert Panel } \\
\text { - as reason for scrapping the } \\
\text { Panel - do you remember this? } \\
\text { There's going to be a } \\
\text { [WITHHELD] Question coming } \\
\text { to us sooner or later... } \\
\text { The only thing I remember was } \\
\text { that we were having challenges } \\
\text { with the whole decision-making } \\
\text { procedure. That's when we came } \\
\text { up with this options piece..." }\end{array}$ \\
\hline $\begin{array}{l}\text { Ge82 } \\
12 / 02\end{array}$ & $\begin{array}{l}\text { DCO } \\
\text { Country } \\
\text { Review }\end{array}$ & $\begin{array}{l}\text { Panel of } \\
\text { Experts - } \\
\text { Simulation } \\
\text { s?? }\end{array}$ & $\begin{array}{l}\text { Simulations } \\
\text { were not } \\
\text { run }\end{array}$ & $\begin{array}{l}\text { Minister is } \\
\text { lying to } \\
\text { justify } \\
\text { unfair } \\
\text { measures }\end{array}$ & $\begin{array}{l}\text { "A quick answer: no such } \\
\text { simulations were run to the best of } \\
\text { my knowledge. I was tasked with } \\
\text { the technical set-up of the panel } \\
\text { once I arrived in May and would } \\
\text { definitely have been involved. We } \\
\text { may have had timelines, at best. } \\
\text { FYI in his comments the Minister } \\
\text { cannot specify when or how the } \\
\text { simulations were run - he } \\
\text { switches into an explanation of } \\
\text { why it was burdensome..." }\end{array}$ \\
\hline
\end{tabular}

During this second stage of coding, all pertinent texts were again scanned several times in order to extract all possible content corresponding to the selected variables. New links and subthemes constantly emerged from the data during this stage of data collection and the codes were revised accordingly. As previously stated, content analysis is a consistent method of providing reliable evidence in order to answer the research question 
(Trimble \& Treiberg, 2011). It was also revealing to note what information the government had obscured and which types of correspondence were withheld. After the data had been adequately coded, it was further organized into subthemes with corresponding examples and quotes (see Figure 1, Appendix B, p. 66; for an example of a possible theme, Designated Country of Origin, see Figure 2, Appendix B, p. 66). Each theme was broken down into concise pieces of evidence that when linked together helped to structure the findings and final argument. In the style of successive approximation, which allows the researcher to go from vague impressions and concrete details in the data to comprehensive analysis with generalizations (Neuman, 2011), a final analysis was constructed. In addition to DCO criteria being applied to Mexico, with statistical evidence and case studies to contend its label of a safe country, the final analysis looks at elements of the discriminatory nature of the PCISA and the neoliberal discourse that has criminalized Mexican refugees in Canada. 


\section{CHAPTER 4: FINDINGS}

\section{The Social Context of the DCO Policy}

Protecting Canada's Immigration Systems Act (PCISA), came into effect on December 15, 2012. The measures included in Bill C-31 built on the reforms passed in the Balanced Refugee Reform Act (BRRA) in June of 2010. Included in this Bill was the introduction of Designated Countries of Origin and the Ministerial power to label countries "safe". The Canadian government defines Designated Countries of Origin as countries that do not normally produce refugees, respects human rights, and offer mechanisms for state protection (CIC, 2013a). According to DCO policy, it would be highly unlikely that a country producing refugees that the United Nations High Commissioner for Refugees (UNHCR) has designated for resettlement could be deemed a DCO (P. Norton, internal communication, February 24, 2012). The changes approved in PCISA amended the criteria used to identify countries to be considered for designation, and removed the requirement to have an expert panel make a recommendation to designate, resulting in concern and consternation from advocacy groups.

The justifications for the enforcement of this discriminatory Bill, which will be explored later on, are long lists of often-iterated statements from former Minister of Immigration Jason Kenney regarding the 'generosity' of Canada's immigration system. The most often statement given by the government is that Bill C-31 accelerates the process for genuine refugees and accelerate the removal of those refugee claimants deemed to be 'bogus'. These new measures also aimed to accelerate the processing of refugee claims for nationals from designated countries of origin (Kenney, 2012). The main goals of these procedures, according to Kenney (2012), are to prevent so-called abuse of the Canadian immigration system and, in a time of fiscal restraint, to ensure that the asylum system is as 
streamlined as possible while remaining fair. Designation is not automatic. A country would have to meet one of two quantitative thresholds or limits based on rejection, withdrawal and abandonment rates (Department of Justice Canada [JUS], 2012). Once a country is triggered for assessment, CIC conducts a country review in consultation with other government departments. However, regardless of the outcome of this consultation, it is the Minister who will make the final decision to designate a country.

Under the DCO policy, claimants from designated countries will continue to have the merit of their claims heard on an individual basis by first-level decision makers at the Immigration and Refugee Board. However, the time-lines for DCO claimants will be expedited. They will be subject to different processing procedures, including a bar on access to the Refugee Appeal Division, and removals will be prioritized (Canada, 2012a). UNHCR does not oppose the introduction of a "designated" or "safe country of origin" list as long as it is used as a procedural tool to prioritize or accelerate the examination of applications in carefully circumscribed situations. Furthermore, it is stressed that decisions must be based on individual cases and that it may be that despite general conditions of safety in the country of origin, for some individuals, members of particular groups or relating to some forms of persecution, the country remains unsafe (UNHCR, 2012).

Within the data were also many statements passed around between government colleagues highlighting the arguments against Bill C-31 and in particular the list of Designated Countries of Origin. The majority of examples argued that the Bill violated the basic principles of justice in the following ways: limited access to Refugee Appeal Division; DCO policy faster timelines and retroactive application; and mandatory detention without review (E. Pease, internal communication, May 8, 2012). 


\section{What does it mean to be from a Designated Country of Origin?}

A Designated Country of Origin is considered a country that normally does not produce refugees and where asylum claimants from that country have a high rejection rate in Canada. As stipulated in Protecting Canada's Immigration System Act, refugee claimants from designated countries may be faced with the following legal consequences:

- Different time limits to provide documents, in particular the Basis of Claim document, and for the scheduling of a hearing

- Lack of access to the Refugee Appeal Division (RAD) if claim is rejected

- Denial of a statutory stay of removal

Various problems arise from these restrictions especially the lack of access to appeal. Although Canada argues that the accelerated time lines for DCO claimants means that "those who truly need our help will get it even faster" (Kenney, 2012), it means something very different for the claimants themselves. One is given only 15 days to complete the Basis of Claim (BOC) form and the hearing before the IRB takes place 45 days after arrival. If a claim is made from inside Canada, the hearing takes place within 30 days of the claim being sent to the IRB. For any individual in a new country, often with a new language, this is a daunting task. Documents that act as evidence for one's case are due 10 days before any hearing at the IRB. This means that refugee claimants from DCOs have only 35 days to gather all the evidence necessary to prove their claim. This often includes newspaper articles, clippings, police reports etc. which all must be originals and from the country of origin, making these time limits a big problem.

In addition to the legal restrictions, there are limited social benefits for refugee claimants from DCOs. Claimants from these countries will be ineligible to apply for a work permit and associated benefits until their claim is approved by the IRB or it has been in the system for more than 180 days without a decision (Kenney, 2012). The Canadian 
government also decided to cut health care services for refugees under the Interim Federal Health Program (IFHP). This means that different types of refugee claimants have different levels of medical services. The only health care services that will be covered for DCO claimants are services related to public health and safety which includes health services to diagnose, prevent, or treat a disease that is a risk to public health or that is a public safety concern (CIC, 2013b).

Finally, if a claimant from a DCO country receives a negative decision, they cannot apply for a Pre-Removal Risk Assessment (PRRA), a review of the risk of danger or persecution one would face in their country before deportation, for 36 months after the decision is made. This means that claimants are often deported without the risk of danger or persecution being reviewed. To be effective, Kenney (2012) states that, "faster decisions must be complemented by timely removals." DCO claimants along with those determined to have a manifestly unfounded claim or a claim with no credible basis, would not have access to the Refugee Appeal Division (RAD). Additionally, refugee claimants who were subject to an exception in the Safe Third Country Agreement and those who arrive as part of a designated irregular arrival would also not have access (Department of Justice Canada [JUS], 2012).

\section{Designation Process}

The designation process of a country is lengthy and seems to be taken up more with bureaucracy and administration rather than actual research and ministerial recommendation. Due to the fact that the qualitative requirements, as well as the designation process, were removed from legislation with the assent of Bill C-31, the process of determining a safe country of origin is merely based on policy recommendations (CIC, Refugee Affairs Branch (RAB), 2012c). If a country meets the requirements for assessment as stipulated in 
legislation, the country automatically initiates a "Trigger Report" (CIC, Monitoring, Analysis and Country Assessment Division [MACAD], 2012a). The country is added to preliminary list for triggered countries, which identifies high priority countries. After a country is triggered for assessment, a DCO country review takes place. Based on a set of DCO assessment indicators, the country review will include input from Government of Canada partners through an Interdepartmental Country Review Committee, and will result in a report containing information on the human rights and state protection situation in the country under consideration (E. Lazar, internal communication, March 8, 2012). Actual country assessment to support policy advice on a potential DCO designation is done by the Monitoring, Analysis and Country Assessment Division (MACAD) of the Refugee Affairs Branch (RAB) (E. Lazar, internal communication, February 24, 2012).

Based on the DCO Country Review, the Asylum Policy Division of RAB will draft a Memo to the Minister presenting advice and/or recommendations regarding potential designation of countries, including considerations identified by partners (CIC, RAB, 2012c). According to a Memorandum to the Deputy Minister, "the DCO Country Review will not provide an evaluative conclusion on whether to recommend a country for designation" (CIC, RAB, 2012c). Final authority for designation rests with the Minister, who is not legally bound to follow the recommendations produced from the Country Review. Subsequent to the designation of a country and its addition to the list of DCOs, an annual review of country designations takes place. However, there was no mention of or information regarding this annual review to be found through the Access to Information Request. 


\section{DCO Requirements}

\section{Quantitative - Triggers}

Quantitative thresholds are stipulated by Ministerial order as a) a combined refusal, withdrawal and abandonment rate of $75 \%$ or higher; or b) a combined withdrawal and abandonment rate of $60 \%$ or higher (CIC, RAB, 2012c). The exact wording as stipulated in legislation is as follows:

DCO Review Thresholds:

Section (i)

"if the rate, expressed as a percentage that is obtained by dividing the total number of claims made by nationals of the country in question that, in a final determination by the Division during the period provided for in the order, are rejected or determined to be withdrawn or abandoned by the total number of claims made by nationals of the country in respect of which the Division has, during the same period, made a final determination is equal to or greater than the percentage provided for in the order, or"

Section (ii)

"if the rate expressed as a percentage, that is obtained by dividing the total number of claims made by nationals of the country in question that, during the period provided for in the order, are finally determined by the Division to be withdrawn or abandoned, by the total number of claims made by nationals of the country in question in respect of which the Division has, during the same period, made a final determination is equal to or greater than the percentage provided for in the order,..."

(C. Kunz, internal communication, March 7, 2012)

To ensure that these rates are stable, the Ministerial Order specifies that quantitative triggers will only apply for countries having at least 30 finalized claims in any consecutive 12-month period in the three years proceeding designation (C. Kunz, internal communication, March 7, 2012). This does not include any countries with a higher than $25 \%$ acceptance rate and with less than thirty claims in the last year (M. Davidson, internal communication, February 15, 2012). In addition, to trigger a review a country's nationals must have made up at least $1 \%$ of the total number of claims in any consecutive twelvemonth period in the three years before the designation date (P. Norton, internal 
communication, February 24, 2012). For claimants from countries with a low number of claims, a qualitative checklist is established in legislation. The qualitative criteria checklist includes the existence of an independent judicial system, the recognition of basic democratic rights and freedoms, and the existence of civil society organizations (JUS, 2012). Countries are then prioritized for review based on claim volume (M. Davidson, internal communication, February 15, 2012).

According to answers prepared by CIC for Question Period, these values were chosen to be the specific target values because they show that the majority of claimants from some countries are determined to be not in need of protection by the independent Immigration and Refugee Board (IRB) and allow for flexibility to review those countries for possible designation (Canada, 2012b). It is restated over and over in government discourse that it is important to note that countries that meet either of the quantitative triggers will not be designated automatically. Regardless of the country, CIC still conducts a review and interdepartmental consultation and provides a recommendation to the Minster who will decide whether or not to designate a country. Throughout the various examples of discourse and communications provided through the Access to Information Request one is constantly reminded that despite the DCO label, every claimant will have their case

determined on its own merits by the Refugee Protection Division of the IRB. However, the association between DCOs and 'bogus refugees' makes this stigma hard to shake, a fact that is never mentioned among government discourse.

\section{Qualitative - Country Review}

Once a country is triggered for evaluation, a country review takes place. The country review framework is based on three major qualitative triggers as part of the DCO policy: the existence of an independent judicial system, basic democratic rights and 
freedoms and options for redress if they are infringed, and the existence of civil society organizations (P. Norton, internal communication, February 24, 2012). These criteria will be assigned performance indicators, and will align with the international human rights instruments - including relevant UN conventions - to which Canada is signatory (U. Chauhan, internal communication, March 29, 2012a). The criteria is also consistent with the qualitative checklist for DCO triggers that is enshrined in legislation. Input in the DCO Country Review from Government of Canada partners will be included though an Interdepartmental Country Review Committee. The country review framework reflects a number of key performance indicators which would report on the prevalence of these factors within the countries under review. It will be used to further review country conditions once those countries meet either the quantitative or qualitative triggers being set out in legislation and Ministerial Order, and to develop advice and recommendations with respect to designation (E. Bauman, internal communication, March 30, 2012).

The DCO Country Review is a concise report which is not evaluative in nature, rather it contains qualitative descriptions of indicators in narrative form (CIC, MACAD, 2012b). The DCO country Review will receive Director-level approval and will be provided to the ADM for information (CIC, RAB, 2012c). To ensure maximum independence and integrity, no revision to the DCO Country Review will take place once it is approved (CIC, RAB, 2012c). The country review will report on the conditions of democratic rights, civil rights, and state protection mechanisms for the country in question. Publically available and classified sources will be consulted, as well as input solicited from other Government Departments via an Interdepartmental Country Review Committee led by the Monitoring, Analysis, and Country Assessment Division (MACAD) of CIC (CIC, $\mathrm{RAB}, 2012 \mathrm{c})$. The working group will include representation from within CIC as well as 
from CBSA, DFATD, Public Safety, the RCMP, and Canadian Security Intelligence Service (CSIS) (CIC, RAB, 2012c). Other considerations related to the overall impact of designation on the department and partners (e.g. visa policy, trade and diplomatic impacts) will also be taken into consideration (CIC, RAB, 2012c). The three main qualitative requirements are then further broken down into the following categories to be reviewed by the Country Review Committee:

Democratic Rights

Free and Fair Elections

Freedom of Opinion and Expression

Freely Functioning Civil Society and NGOs

Civil Rights

Right to Liberty and Security of the Person

Protection from Non-State Actors and Organized Crime

Protection Afforded to Vulnerable Persons

State Protection Mechanisms

Access to Law Enforcement

Access to Independent Judiciary

Access to Legal Remedy

(CIC, MACAD, 2012b)

In a document prepared by MACAD outlining the proposed set of criteria and indicators for the DCO Country Review, human rights and state protection mechanisms related to refugees are described further. According to the Immigration and Refugee Protection Act (IRPA) 96 and 97, the risk of human rights violations, including persecution, torture and other forms of cruel and unusual treatment or punishment, are the key grounds for refugee protection in Canada (IRPA, 2001). Therefore, protection against these violations is an essential component for designation of a country as "safe" (CIC, MACAD, 2012a). Human rights and freedoms related to refugees are also outlined in detail in key international conventions signed by Canada, including the International Covenant on Civil and Political Rights (ICCPR), Convention Against Torture (CAT), Convention on the 
Elimination of All Forms of Discrimination Against Women (CEDAW), Convention on the Elimination of All Forms of Racial Discrimination (CERD), and Convention on the Rights of the Child (CRC). These include the right to life, liberty and security of the person (including freedom from torture and other cruel or degrading treatment or punishment); freedom of opinion and expression; freedom of religion, assembly, and association; and freedom from persecution for specific at-risk groups such as women; children, and minority groups (CIC, MACAD, 2012a). Protection of human rights is a key component to a country's eligibility for DCO designation. IRB acceptance rates are key quantitative triggers for DCO review, and IRB decisions are based on the human rights protection grounds enshrined in IRPA (CIC, MACAD, 2012a). According to a report produced by MACAD (2012a), a state's ability to protect these rights will tend to lead to low acceptance rates and thus trigger a country for DCO review. In addition to basic democratic rights and freedoms, state protection is highly emphasized among qualitative triggers for DCO Review in the PCISA. Refugees must seek international protection from persecution when their own state either cannot or will not provide protection, as international protection is a surrogate for national protection (CIC, MACAD, 2012a). Measures for protection from persecution and remedy of persecution are also listed as fundamental rights in key international conventions signed by Canada, including the ICCPR and CAT. Best practices consistent with refugee protection division practice and Canadian case law state that "the best rubric under which to examine the questions of adequacy of state protection against private individuals include(s) questions of the efficacy of the judicial system, the police and legislative frameworks" (CIC, MACAD, 2012a). Thus indicators are included on the right to impartial investigations, a fair public trial, and adequate legal remedies for rights violations. The existence of an independent judiciary and the presence of "mechanisms for 
redress" for violations of democratic rights are listed among the qualitative triggers for DCO Review in the Protecting Canada's Immigration System Act (PCISA). These are common criteria for the designation of "safe" countries among several EU countries with DCO policy including Belgium, France, Finland, Germany and Ireland.

Although an in-depth review is conducted to determine if designation may be appropriate, under the provisions established in Bill C-31, the necessary criteria to be considered in the country review was removed from the legislation. The factors are set out in policy, and used consistently when reviewing countries for possible designation, providing for greater flexibility if adjustments are required (U. Chauhan, internal communication, March 29, 2012b). The PCISA contains no legislative mention of a country review or even this step in the designation process. The Minister is only required by legislation to have the country meet a threshold (what is referred to as a "trigger") as set out in Ministerial Order, before designation happens (E. Pease, internal communication, May 8, 2012). With the Ministerial power granted to designate countries without a positive recommendation from a panel of experts, the Minister no longer has to follow the advice given in the country review. (CIC, RAB, 2012b) This leaves the designation of countries open to various biases, including economic and diplomatic reasons.

The legislation on DCO Review content is detailed and makes mention of both sections 96, 97 of IRPA, and UN Conventions but only requires the Minister to take this criteria into account, rather than legally holding him accountable for fair designations. The exact language as stipulated by the legislation regarding DCO Country Reviews is as follows: 
109.1 (1) The Minster may, by order, designate a country, for the purposes of subsection 110(2) and section 111.1...

Clause 58: Text of enacted section 109.1:

109.1 (1) The Minister may, by order, for the purposed of section 111.1 designate a country or part of a country or a class of nationals of a country.

(1.1) The Minister may make a designation only if

(a) the number of claims for refugee protection made in Canada by nationals of the country in question is equal to or greater than the number set out in the regulations; and

(b) the rate of acceptance by the Refugee Protection Division of claims made by nationals of the country in question is equal to or lower than the rate set out in the regulations.

(1.2) In making a designation, the Minister must take the following criteria into account:

(a) the human rights record of the country in questions as it relates to

(i) the factors set out in sections 96 and 97, and

(ii) the international human rights instruments specified in the regulations and any other international instrument that the Minister considers relevant;

(b) the availability in the country in question of mechanism for seeking protection and redress;

(c) the number of claims for refugee protection made in Canada by nationals of the country in question;

(d) the rate of acceptance by the Refugee Protection Division of claims made by nationals of the country in question and the rate of appeals allowed by the Refugee Appeal Division in respect of appeals made by nationals of the country in question; and

(e) any other criteria set out in the regulations

Clause 59: Text of enacted section 111.1:

111.1 (1) The regulations may provide for any matter relating to the application of this Division, and may include provisions

(a) relating to the criteria referred to in subsection 109.1 (1.2) and the process to be followed with respect to a designation made under subsection 109.1(1);

(b) establishing criteria for the purposes of paragraph 109.1 (1.2)(e); and

(c) respecting the time limits

(i) for the hearing referred to in subsection 100(4.1),

(ii) for the filing and perfecting of an appeal under subsection 110(2.1), and

(iii) for the making of a decision by the Refugee Appeal Division, the extension of those time limits and the circumstances under which they do not apply.

(E. Bauman, internal communication, March 1, 2012)

\section{Justifications}

There are several recurring justifications of the measures set out in Bill C-31, most of which argue for the protection of Canada's immigration system rather than the protection 
of vulnerable persons at risk. The main arguments for Bill C-31 and the Designated Countries of Origin policy are that the policy would streamline the asylum system to result in faster processing (reducing the backlog) and create more flexibility in the process for designating countries of origin to respond more quickly to spikes in refugee claims from countries that don't generally produce refugees (CIC, RAB, 2012a).

Kenney's familiar iterations about the generosity of Canada's immigration system and refugee programs appear in every question period, briefing note, and press release. Bill C-31 Protecting Canada's Immigration Systems Act is said to strengthen the fairness and integrity of Canada's immigration and refugee programs and to protect Canada from the masses of people making "bogus refugee claims" (Kenney, 2012). As stated by Kenney (2012), the Canadian government is very concerned about the recent increase in refugee claims from democratic countries that respect human rights. The asylum system is overwhelmed by a large backlog of cases and it is argued again and again that, "too many tax dollars are spent on people who do not need our protection" (Kenney, 2012). When speaking of "people who do not need protection," Kenney (2012) is referring to those refugee claimants that come from countries that do not typically produce refugees and respect democratic rights. The DCO policy is said to help to streamline Canada's asylum system and reduce abuse of the system by those who are not in need of Canada's protection. The changes embedded in this policy enable the government to respond more quickly to spikes in refugee claims from countries that do not have a history of producing refugees.

Many of the justifications and arguments for the DCO policy have to do with timelines and the ability to speed up the refugee claim process. By allowing the Minister to have the power to designate, it is argued that the government will be able to respond 
quickly to changes in immigration trends. Kenney (2012) phrases this trend as "organized waves of fake claims from safe democratic countries," rather than acknowledging that country conditions change with time. The expedited timelines and the bar on appeal (as described above) means that the number of options for claimants from DCOs, as well as their time spent in Canada, is significantly decreased. In the words of Kenney (2012), "We will limit access to taxpayer-funded social benefits and work permits for refugee claimants from designated countries of origin to reduce the pull factors that often bring people here to Canada with illegitimate claims."

Kenney (2012) often uses the words "manifestly unfounded," "bogus," and "criminal," when describing refugee claimants whose cases have been rejected. This association of claimants from democratic countries with criminals is well documented and Kenney uses this rhetoric to defend the DCO policy. The language and associations used in government discourse have created a stigma for refugee claimants from so-called "safe" countries which will be explored in Chapter 5. Included in Bill C-31 are also the measures for a biometric visa system, which the Canadian government says will make "fake" applications virtually impossible. As Kenney (2012) stated, “...we have seen many cases of people, criminals, foreign criminals arrested, convicted and deported who came back to Canada using fake papers. Under the biometric visa system... it will substantially improve immigration security and ensure as well that deported failed refugee claimants don't return on fake papers."

Other new policy measures outlined in Bill C-31 are the bar on appeal (RAD) for claimants from DCOs and the inability of refugee claimants from these countries to apply for a work permit and associated benefits until their claim is approved by the IRB (Kenney, 2012). This policy measure, in particular the lack of avenues to appeal, raises serious 
concern among refugee advocates. To justify this ban on the Refugee Appeal Division for claimants from DCOs, Kenney (2012) again invokes the timelines and the abuse of Canada's Immigration System. In order to be effective, the Canadian government argues that faster decisions must be complemented by timely removals, not allowing claimants to remain in Canada for years using endless appeals at the expense of Canadian taxpayers (Kenney, 2012). However, when challenged on the lack of appeals for DCO claimants during a Question Period, Kenney simply stated that, "The UNHCR has recognized that measures such as the DCO policy can be appropriate for fast tracking claims from certain countries. A number of liberal democracies, including the UK and Australia, have a similar DCO authority" (CIC, RAB, 2012b).

Finally, the most disturbing justification arises from the removal of the panel of experts in order to make a designation. Previously, as stipulated in Bill C-11 The Balanced Refugee Reform Act (BRRA), the Minister needed a positive recommendation from a committee including human-rights experts. Now, with the PCISA, the power to designate a "safe" country rests solely with the Minister, who may remain completely uninformed about the conditions of a country. Although it is stated in policy that the Minister must heed the recommendations of the interdepartmentally produced country Review, there is nothing in legislation that requires him to follow any advice other than his/her own. When challenged on this point at a news conference, Kenney states that the problem with the system proposed in Bill C-11 was that it was too cumbersome and too slow" (Kenney, 2012).

When pressed further on this issue and specifically asked how he knows it is a slow moving process since it was never actually implemented, Kenney responds that his department "actually kind of ran some simulations, and we realized it was going to take us 
months to be able to designate countries, and we need a faster tool," (E. Bauman, internal communication, February 17, 2012). Kenney continues on to explain that since the bill was adopted, the department has looked more closely at the effect of those amendments, and the kind of very slow moving process of the panel to recommend designated countries (E. Bauman, internal communication, February 17, 2012). After being asked more about the simulations and if there was any data available from them, Kenney bumbles around the issue and explains again why the panel of experts is a burdensome process. Upon further reading of the data provided by the Access to Information Request, it becomes clear that there never were any simulations run, with numerous departmental emails circulating questions these "simulation" proving that Minister Kenney was lying in order to justify an unfair and discriminatory policy measure. 


\section{CHAPTER 5: ANALYSIS}

\section{Does Mexico Meet the Criteria?}

In order to determine whether Mexico rightfully belongs on the list of Designated Countries of Origin, the DCO criteria was applied to Mexico and the results examined.

\section{Quantitative Requirements}

As previously mentioned, the quantitative thresholds stipulated by Ministerial order are a combined refusal, withdrawal and abandonment rate of $75 \%$ or higher; or a combined withdrawal and abandonment rate of $60 \%$ or higher (CIC, RAB, 2012b). Quantitative triggers only apply for countries having at least 30 finalized claims in any consecutive 12month period in the three years proceeding designation (CIC, RAB, 2012c). This does not include any countries with a higher than $25 \%$ acceptance rate and with less than 30 claims in the last year (M. Davidson, internal communication, February 15, 2012).

The data used to examine Mexico's claim rates comes from the IRB released through an Access to Information Request and made public by the Canadian Council for Refugees (CCR). The statistics (including recognition rates) for each year include only principal applicant claims (i.e. excluding associated claims by family members of principal applicants) (CCR, 2014). The data refers to "recognition rates," a term used to mean the proportion, expressed as a percentage, of positive decisions relative to the total number of positive and negative decisions, excluding cases that are abandoned, withdrawn or otherwise resolved. This is the standard practice for reporting outcomes by the United Nations High Commissioner for Refugees, and it is the way that both "recognition rates" and "grant rates" were reported for data obtained for prior years (CCR, 2014).

The relevant IRB data for the three years prior to Mexico's designation $(2010,2011$, 2012) is as follows: 


\begin{tabular}{|l|l|l|l|l|l|l|}
\hline Year & $\begin{array}{l}\text { Abandoned/ } \\
\text { Withdrawn }\end{array}$ & $\begin{array}{l}\text { Neg. No } \\
\text { Cred. Basis }\end{array}$ & Negative & Positive & $\begin{array}{l}\text { Recognition } \\
\text { rate }\end{array}$ & Total \\
\hline 2012 & 237 & 60 & 1097 & 262 & $18.5 \%$ & 1,656 \\
\hline 2011 & 877 & 132 & 4,038 & 1,021 & $19.7 \%$ & 6,068 \\
\hline 2010 & NA & 71 & 1731 & 286 & $13 \%$ & 2,088 \\
\hline
\end{tabular}

(CCR 2013; CCR 2012; CCR 2011)

2012 rejection rate $=$ abandoned $/$ withdrawn + neg. no cred. basis + negative $/$ total $=84.2 \%$ 2012 abandonment rate $=$ abandoned $/$ withdrawn $/$ total $=14.3 \%$

2011 rejection rate $=$ abandoned $/$ withdrawn + neg. no cred. basis + negative $/$ total $=83.2 \%$ 2011 abandonment rate $=$ abandoned $/$ withdrawn $/$ total $=14.5 \%$

2010 rejection rate $=$ (data not available for abandoned/withdrawn) but with neg. no cred. basis + negative $/$ total $=>86.3 \%$ which already surpasses the necessary criteria 2010 abandonment rate $=$ data not available

In both 2012 and 2011, the rejection rate meets the DCO quantitative criteria of $75 \%$ or higher with $84.2 \%$ and $83.2 \%$ respectively. The other quantitative requirement, an abandonment rate of $75 \%$ or higher, is not met with only $14.3 \%$ and $14.5 \%$. Nevertheless, meeting only one of the requirements is enough to trigger a DCO country review. In 2010, the data for abandoned and withdrawn cases is not available publicly but with a negative rate of $86.3 \%$, it is certain that the rejection rate would also meet the DCO criteria.

Claimants from Mexico processed through the IRB in the three years preceding designation in 2013 , meet the quantitative trigger of $75 \%$ or higher with ease. What is not close to being met is the abandonment or withdrawal rate of $60 \%$ or higher, possibly negating the claim that the majority of refugee claims from Mexico are unfounded or 'bogus.'

It is important to note the changes that the visitor visa requirement may have had on the IRB data available. The majority of the cases processed in the three years preceding designation were backlogged cases. There was an influx of refugee claims from Mexico referred to the IRB in the 2000 , an immigration trend which is often referred to in 
government rhetoric as "huge waves of unfounded claims from democratic countries" (Kenney, 2012). The number of claims from Mexico rose steadily from 1,317 in 2000 to a high of 9,322 in 2009 (IRB, 2011). This trend correlates with the increase of violence in the 2000s surrounding the drug war, however it is impossible to say that this was the reason for the large increase in refugee claims since the basis of claim of each case is not public information. The Canadian government responded to this surge in claims by announcing a visa requirement for all Mexicans wishing to travel to Canada on July 13th 2009, effective the next day. The new visa rule took the Mexican and Canadian general public by surprise, but the Harper government had apparently discussed this possibility with the Calderón administration in November 2008 (Gilbert, 2013b). After the visa requirement took effective, the number of claims in 2010 , the following year, dropped to 1,299 , an enormous difference from the over 9,000 refugee claimants referred to the IRB in 2009.

\begin{tabular}{|l|l|l|l|l|}
\hline Year & $\begin{array}{l}\text { Ref. to } \\
\text { IRB }\end{array}$ & Accepted & $\begin{array}{l}\text { Acc. } \\
\text { \% }\end{array}$ & $\begin{array}{l}\text { Total Refugees } \\
\text { Accepted }\end{array}$ \\
\hline 2000 & 1,317 & 322 & 26 & 13,999 \\
\hline 2001 & 1,649 & 239 & 20 & 13,383 \\
\hline 2002 & 2,345 & 292 & 24 & 15,459 \\
\hline 2003 & 2,564 & 600 & 27 & 17,631 \\
\hline 2004 & 2,919 & 674 & 25 & 15,948 \\
\hline 2005 & 3,550 & 709 & 19 & 12,090 \\
\hline 2006 & 4,958 & 933 & 28 & 9,296 \\
\hline 2007 & 7,080 & 383 & 11 & 5,936 \\
\hline 2008 & 8,069 & 606 & 11 & 7,554 \\
\hline 2009 & 9,322 & 515 & 8 & 11,203 \\
\hline 2010 & 1,299 & 563 & 11 & 12,305 \\
\hline 2011 & 763 & 1,042 & 17 & 12,983 \\
\hline
\end{tabular}

(IRB, 2011)

Despite the much larger numbers of refugee claims coming from Mexico in the late 2000s, the rejection rate for each year is high, and would still trigger a DCO Country Review for Mexico for any three-year period from 2000 to the present. Again, the only quantitative 
trigger met by Mexico is the rejection rate, and not the abandonment or withdraw rate. With Mexico consistently having high percentages of negative decisions leading to the DCO trigger, the question to explore further seems to be why there is such a high number of negative decisions for refugees from Mexico.

\section{Qualitative}

It is the Minister who characterizes what is a "safe and democratic" country. The 2010 bill stated that a panel of human rights experts was needed in order to make a designation. Now it is solely the minister's responsibility. Without a doubt this gives the Minister too much authority to make decisions about what is and is not a safe country and leaves this decision open to diplomatic and political bias. Despite the fact that the Minister does not need a positive recommendation to designate a country, each country triggered undergoes a country review carried out by MACAD, a process described in the previous chapter. In legislation it is recommended that the Minister follow the advice produced by the committee.

Mexico should not have received a positive recommendation for designation, had the qualifications for a safe country as set forth by CIC been thoroughly examined, in this author's opinion. Regardless of what information or recommendations the country review

produced, the final decision rests with the minister and Mexico was designated safe.

Unfortunately, these country reviews, and any country-specific information, are not available, even through the Access to Information Act, and therefore the results of the DCO Country Review of Mexico will always remain unknown.

As discussed in Chapter 4, the country analysis reports on the conditions of democratic rights, civil rights, and state protection mechanisms for the country in question. These three categories are broken down further into subcategories which will be examined 
in the context of Mexico below. While some parts of Mexico remain arguably safe, as a whole, Mexico meets almost none of the criteria of a safe country fit for designation.

\section{Democratic Rights}

Under the category of democratic rights, the DCO Country Review looks at three components: Free and fair elections, freedom of opinion and expression, and freely functioning civil society and NGOs (CIC, MACAD, 2012b). It can be shown that none of these rights are extended to the population at large in Mexico. First, the latest election in which Peña Nieto of the Partido Revolucionario Institucional (PRI) was selected as President, garnered widespread criticism of voter fraud and corruption, on top of the media bias involved. Despite international acceptance of Peña Nieto's presidency, with some criticizing world leaders including Obama for congratulating Peña Nieto before he had actually won the election, most agree that the election was far from fair (Weisbrot, 2012). Currently, Mexico's centralist party (PRI) controls the major TV media (Televisa, TV Azteca, Telemundo etc.) and uses this power to manipulate the electoral process (Weisbrot, 2012). With all major stations controlled by one political party, the media landscape is characterized by a lack of pluralism, as Televisa and TV Azteca hold 90 per cent of free and pay TV concessions (Reporters Without Borders [RWB], 2013). While citizens enjoy

freedom of expression in principle, the authorities fail to uphold freedom of expression by protecting media workers from threats and violence from organized crime groups and the police (Amnesty International, 2012). In 2013, Mexico was declared one of the world's most dangerous countries for journalists who are threatened and murdered by organized crime or corrupt officials with impunity (RWB, 2013). The resulting climate of fear, both of the authorities and the cartels, leads to self-censorship and undermines freedom of information (RWB, 2013). 
Finally, functioning civil society organizations and NGOs do exist, although not in large numbers, with many dedicated to the protection of human rights (UNAM, 2012). However, there are numerous reports of human rights defenders being threatened or attacked in recent years, which has silenced many (Amnesty International, 2012). The government's commitment to respect the work of NGOs has also been called into question with the Minister of the Navy publicly attacking the work of human rights organizations documenting abuses committed by the armed forces (Amnesty International, 2012).

\section{Civil Rights}

Included in the criteria of a safe country is the recognition of civil rights, which include the right to liberty and security of the person, protection from non-state actors and organized crime, and protection afforded to vulnerable persons (CIC, MACAD, 2012b). The first requirement under this category is the most noted right that is not afforded to the population at large. That is, freedom from violence and fear.

Making sense of the violence in Mexico is often challenging because of sensationalistic media reporting, widespread preconceptions, and a lack of access to reliable statistical information. For the purpose of this study violence will be measured using the number of intentional homicides recorded. In Mexico, where there is a high degree of criminal impunity, with fewer than $25 \%$ of crimes reported, and just $2 \%$ of all crimes punished, homicides are more likely to be reported, investigated, and punished than other forms of violent crimes (Molzahn, Rodriguez, \& Shirk, 2013). While all datasets have limitations, the most consistent, complete, and reliable source of official information in Mexico is the autonomous government statistics agency, Instituto Nacional de Estadística y Geografía (INEGI), which provides data on death by homicide and other forms of violent crime (Molzahn et al., 2013). 
The number of homicides recorded by INEGI was 25,757 in 2010, 27,213 in 2011 and 26,037 in 2012, an average of 23 homicides per 100,000 people (Molzahn, 2013; Heinle, 2013). While levels of violence in Mexico are lower than elsewhere in Latin America, Mexico stands out on security issues due to the number and rate of homicides occurring which has escalated quite dramatically in recent years, reversing a multi-decade downward trend (Molzahn et al., 2013). The number of reported homicides had an average annual increase of 24\% from 2006-2012 (Molzahn et al., 2013), statistics that correspond with the sharp increase of Mexican refugee claimants in Canada. Sensational and horrific cases including execution-style killings, assassinations of politicians and journalists, and mass graves have also led to considerable media attention. A large part of this sudden increase in violence in Mexico is attributable to drug-trafficking and organized-crime groups (Molzahn et al., 2013, p. 6).

Drug-related violence is very localized. While some places remain quite secure, others are ridden with violence. For example, Ciudad Juárez had a recorded 2,738 drugrelated homicides in 2010 alone (SNSP in Molzahn et al., 2013). This is a rate of 206 murders per 100,000 residents, ranking Ciudad Juárez as the most dangerous urban area in the world, a title the city held onto for three consecutive years from 2008 - 2010 (Consejo Ciudadano para la Seguridad Pública y la Justicia Penal [CCSPJP], 2012). And Ciudad Juárez, while extreme, is not an anomaly. In the three years prior to designation (2010 2012) that were examined in the DCO country review, Mexico consistently had at least four cities ranked among the most dangerous in the world measured by homicide rate, including Acapulco, Torreón, Chihuahua, Coahuila, and Juárez (CCSPJP, 2013; CCSPJP, 2012).

In addition to high numbers of homicides, many other violent crimes take place on a daily basis in Mexico including kidnappings, assault, torture, extortion, intimidation, and 
other violent crimes. According to estimates by INEGI, there were 105,682 kidnappings in 2012, only 1,317 of which were reported to the police (Zúñiga, 2013). There were also around 6 million cases of extortion, a number which the police put at 7,272 (The Economist, 2013). Using its own figures, Security, Justice and Peace (CCSPJP, 2013), an anti-crime charity, says Mexico is currently the worst place for kidnapping in the world, and that more victims are being killed.

Another criteria under civil rights is protection from non-state actors and organized crime (CIC, MACAD, 2012b), a right afforded to no one in Mexico. As stated above, a large part of the violence in Mexico is attributable to drug-trafficking and organized-crime groups (Molzahn et al., 2013). This is somewhat of an understatement as drug cartels control large areas of the country, exerting more force and power than the authorities. Estimates for the year 2011 run as high as $71.5 \%$ of the country's municipalities being under the control of organized crime groups (Gómora, 2012). These groups or cartels use fear and violent intimidation to extort and abuse civilians.

The final civil right investigated is protection afforded to vulnerable persons. This category is vague but most likely means protection for people who belong to a minority group, be it based on gender, ethnicity, sexual orientation, disability, minor age, low income etc. In theory, Mexico may extend legal protection to so-called minorities, with such regulations included in legislation as Programa Nacional para Prevenir y Eliminar la Discriminación, but these laws are rarely put into practice (Secretaría de Gobernación [SEGOB], 2012). Indigenous Peoples continued to suffer routine discrimination and systemic inequality and violence against women remained widespread (Amnesty International, 2013). 
However, in highly effected areas, the amount of violence, police brutality and corruption (discussed below) and the extent to which organized crime groups exert control, make all the residents in these areas vulnerable persons. It is to these and all vulnerable civilians that state protection is not provided. According to IRPA 96 and 97, the risk of human rights violations, including persecution, torture and other forms of cruel and unusual treatment or punishment, are the key grounds for refugee protection in Canada (CIC, MACAD, 2012a). Protection against these violations is an essential component for designation of a country as "safe" (CIC, MACAD, 2012a).

\section{State Protection Mechanisms}

The final set of criteria for the DCO Country Review is based on state protection mechanisms and includes access to law enforcement, access to independent judiciary, and access to legal remedy (CIC, MACAD, 2012b). This category is particularly biting for it is the state that commits many of the crimes and corruption in Mexico, rather than protecting its citizens. Reports of corruption, bribery, extortion, assault, torture, kidnapping, unlawful killings, illegal searches, planting evidence, theft, and excessive use of force by municipal, state, and federal police are common place in Mexico (Amnesty International, 2012; Associated Press, 2012; Stevenson, 2011; Tuckman 2012). Regularly, Mexican government officials at every level, along with the police and military, work together with the cartels in a complex network of corruption (Vulliamy, 2010). The military connection should come at no surprise as U.S. Army Intelligence statistics out of Leavenworth, show that over a sixyear period, 150,000 of the 250,000 soldiers in the Mexican Army deserted to join drug cartels (Bowden, 2010). In addition, the Mexican federal government has been accused of favouring the Sinaloa cartel during the drug war and protecting its leader, Joaquín "El Chapo" Guzmán (Burnett, Peñaloza, \& Benincasa, 2010). 
In the criteria for DCO Country Reviews it states that refugees must seek international protection from persecution when their own state either cannot or will not provide protection, as international protection is a surrogate for national protection (CIC, MACAD, 2012a). Situations where states fail to protect include persecution committed by the state, persecution condoned or tolerated by the state, and persecution present because the state is unable to protect (CIC, MACAD, 2012a). Measures for protection from persecution and remedy of persecution are listed as fundamental rights in key international conventions signed by Canada, including the ICCPR and CAT (CIC, MACAD, 2012a).

In addition to access to law enforcement, access to independent judiciary and legal remedy are also to be taken into consideration during country review. In policy these two legal rights are upheld, with Mexico's judiciary being a separate branch of government since independence, and judicial relief available through the exercise of civil law jurisdiction. In practice, however, these rights are not upheld and a high level of criminal impunity, bribery, and corruption exist in the court system (Molzahn et al., 2013; Amnesty International, 2012). The criminal justice system often falls short of international fair trial standards, facilitating politically motivated prosecutions, unsound convictions and the widespread use of arbitrary pre-charge detention orders (arraigo) (Comisión Mexicana de Defensa y Promoción de los Derechos Humanos [CMDPDH], 2012; Amnesty International, 2012). Those responsible for the misuse of the criminal justice system have never been held to account (Amnesty International, 2012).

Protection of human rights is a key component to a country's eligibility for DCO designation (CIC, MACAD, 2012a).

As this analysis has shown, it is highly unlikely that Mexico would have produced a positive recommendation based on a country evaluation of the years 2010-2012. 


\section{Government Advisories}

Perhaps the biggest contradiction of Mexico's designation, is Canada's own travel advisory warning, on the same website that lists Mexico as a safe country. As of May 30, 2014, there are the following regional advisories for Mexico:

Foreign Affairs, Trade and Development Canada advises against non-essential travel to the northern states of Chihuahua, Coahuila, Durango, Nuevo León (except the city of Monterrey), Sinaloa (with the exception of Mazatlán), Sonora (except the cities of Hermosillo and Guaymas/San Carlos), and Tamaulipas due to continuously high levels of violence linked to organized crime. Foreign Affairs, Trade and Development Canada also advises against nonessential travel to the south western states of Michoacán (excluding the city of Morelia) and Guerrero (excluding the cities of Ixtapa, Taxco and Zihuatanejo, as well as the tourist zone of Acapulco) due to the high levels of violence and organized crime. Exercise a high degree of caution in the excluded areas. (Government of Canada, 2014).

The warnings written and disseminated by the Canadian government go on to detail the proliferation of crime and corruption happening in Mexico. Keep in mind these are recommendations for people travelling to Mexico, not for those living in Mexico. For residents of Mexico, owning property or a business poses an extra threat as extortion runs rampant through every sector of society, from taco stands to real estate, teachers to priests (Wilkinson, 2012). Despite the advisories' limitation to travellers, they still demonstrate a lack of security of the person and protection from organized crime.

The travel advisories posted on the Canadian government website, last updated on May 30, 2014, include the following statements:

Crime rates in Mexico are high.

Shootouts, attacks and illegal roadblocks may occur without warning. Armed clashes between security forces and criminal groups do occur in certain areas without warning.

...theft and carjacking along highways... Avoid inter-city road travel in the northern states... Travel to and within Ciudad Juarez poses particular challenges and requires extreme caution... Avoid road travel at night... avoid movement after dark. 
The deterioration of the security situation is particularly noticeable in the rural areas of Guerrero and Michoacán. The rapid expansion of vigilante militias is troubling, and there have been instances where such groups have fired at vehicles that did not adhere to their roadblocks.

In northern Mexico, particularly along the border with the United States, organized crime and urban violence affect security. Confrontations between organized criminal groups and Mexican authorities continue to pose a problem. This has led to an increase in illegal roadblocks, robberies, kidnappings and carjackings.

Law enforcement and police presence is often lacking near the border with Guatemala, particularly in the state of Chiapas.

Heavily armed gangs have attacked travellers driving through Matamoros, Reynosa, and Nuevo Laredo in the state of Tamaulipas but also on several highways in the states of Nuevo León, Coahuila, Durango, and Sinaloa. Violence related to organized crime has increased in the states of Guerrero (including Acapulco), Sinaloa (including Mazatlán), Morelos, Nayarit, Michoacán, San Luis Potosi, Veracruz, and Zacatecas, and Jalisco.

Theft, including armed robbery, is common in Mexico... Virtual kidnapping and express kidnapping are common practices in Mexico... Legitimate police officers have extorted money from tourists [and residents, citizens etc.] and arrested tourists for minor offences or traffic violations.

(Government of Canada, 2014)

Despite the interdepartmental nature of the DCO country reviews, somehow the message did not get through that some parts of Mexico are not safe places. The Canadian government contradicts its own qualitative criteria of a safe country in the travel advisories. The civil rights of liberty and security of the person as well as protection from non-state actors and organized crime are not met and this is demonstrated on the same websites that list Mexico as a safe country. A country that Canada openly states is safe for Mexicans, but not safe for Canadians. While the safety of a country may differ depending on the group(s) one identifies with, and whether or not one is perceived as a tourist, the civil right of safety and security of person should be universally applied, not based on nationality. The qualitative requirements for a safe country include human rights, not rights afforded only by those living in Canada. "Shootouts, attacks and illegal roadblocks, ... robberies, kidnappings and carjackings... armed clashes," (Gov. of Canada, 2014) are actions which 
jeopardize the safety of Canadians and Mexicans alike. The fact that the Canadian government openly can declare Mexico safe for those living there but dangerous for Canadians wishes to travel/work/live there is hypocrisy and discrimination at its core. Different standards and rights for human beings based on their citizenship is an example of 'otherness' which has been discussed under many headings, such as prejudice, ethnocentrism, and racism (Nederveen Pieterse, 2002, p. 23). There has been a shift in racism, from notions of biological superiority, to exclusion based on cultural differences and citizenship (Ibrahim, 2005). Looking at this shift, it is possible to see that this new migrant-as-a-threat narrative realizes a racist discourse, made possible through the broadening of the concept of security and the linking of risk and threat to migrants (Ibrahim, 2005). Canada's immigration and refugee legislation as outlined in Bill C-31 offer an example of how this racial discourse informs government policy. The DCO policy is a flawed, exclusionary system which bases the way a refugee is treated on his or her nationality. Despite high numbers of claimants, high levels of violence, a war, Canadian government advisories, and the overwhelming proof that Mexico does not meet the qualitative requirements of a DCO, it was designated as such. It is my belief that Mexico's DCO status was made possible through a discourse of securitization which has lead to the Minister's sole designation power, leaving the door open for politically biased decisions. These issues are explored further below.

\section{The Securitization of Migration - An Oppressive Discourse}

As threat and insecurity are being redefined and broadened, migration has become synonymous with a risk to the Global North. The construction of migrants as a threat to the security of Canadian citizens is a newer development. Such a construction was strengthened by a more familiar fear that migrants would be the demise of Canada as a 
welfare state (Ibrahim, 2005). The Canadian government has framed the influx of Mexicans seeking asylum in Canada as a matter of national security rather than a human-rights crisis in what I believe is a deliberate act of securitization. The government has succeeded in framing refugees as a security threat by means of creating knowledge through government and media discourse.

\section{The Power-Knowledge Nexus}

According to Foucault (1980), “in any society there are manifold relations of power which permeate, characterize, and constitute the social body and these relations of power cannot themselves be established, consolidated, nor implemented without the production, accumulation and functioning of a discourse. [...] We are subject to the production of truth through power and we cannot exercise power except through the production of truth" (p. 93). Thus the production of a truth, or the creation of knowledge through a discourse, is an exercise of power. This is the power-knowledge nexus. New types of discourse are constantly creating new forms of knowledge. The securitization of migration can be examined as a discourse through which relations of power are exercised (Ibrahim, 2005). In Canada, the securitization of migration through discourse has normalized the view that migrants are a threat. This view is particularly troubling because it is the people at risk, escaping war, violence, persecution, and hunger, who are being seen as threats to the receiving country's population. The well-established discourse of migrants as security threats to Canada had led to the exclusionary immigration legislation in Bill C-31. Refugees are now being treated differently on the basis of one's nationality, and are seen as the invader and abuser rather than a human being at risk who needs protection. There is no doubt that this discourse, which has successfully been accepted as the new knowledge, has led to the tolerance of this treatment by the general public in Canada. 


\section{Government Discourse}

In order to create the knowledge or truth that refugee claimants pose a risk, the Canadian government has exercised its power and produced a discourse that has become increasingly familiar in the last decade. This neoliberal discourse adopted by the Conservative government is based on the juxtaposition between bona fide/real refugees and fake/bogus refugees. Embedded in this discourse is the assumption that 'bona fide' or genuinely deserving refugees are in camps overseas whereas claimants who actually arrive in Canada are less in need of protection and consequently less likely to be 'genuine' refugees (Pratt, 2005).

Examples of this juxtaposition can be seen in most CIC documents produced in the last five years, particularly justifications of immigration laws and refugee assistance programs. To realize how ingrained this oppressive discourse of bogus claimants has become, one need not look further than the speech delivered by Jason Kenney at a news conference following the tabling of Bill C-31 on February 16, 2012 in Ottawa. This speech, available publicly but obtained through ATIP, explains and justifies the passing of Bill C31 using the constructed knowledge that Canada's generous system is being abused by bogus and criminal claimants.

(Note: all examples taken from Feb. 16, 2012 speech, underlines are mine)

The first familiar lexicon in this discourse is of the generous system being abused. Refugee claimants are constantly framed as criminals abusing the system, taking advantage of the social benefits Canadians are entitled to. In one short speech, the words generous/generosity are used ten times while the word abuse in the context of refugee claimants is used seven times, often as "abuse our generosity" painting an image of Canada as the innocent victim and many refugee claimants as criminals who game the system. As 
Gilbert (2013b) claims, the discourse of 'illegality' and 'criminality' associated with Mexican migrants in the US has migrated north, and has been extended indiscriminately to Mexican refugee claimants in Canada (p. 829). The dominant narrative about the need to control the alleged abuse of the Canadian refugee system has prejudiced the determination process of Mexican refugee claimants.

“...the fairness and integrity of Canada's generous immigration and refugee programs.”

"...no tolerance for those who abuse our generosity or take advantage of our country."

“...our generous asylum system has been abused by too many people making bogus refugee claims."

"... an encouragement for people who want to come and abuse our generosity."

"We are determined to prevent this abuse of our system..."

"... maintain the integrity of our generous immigration system...while curtailing the abuse of that system..."

"... stop those who mean to do us harm or abuse our generosity."

"If you are a law-abiding immigrant, you're more than welcome in this country."

"...if you intend to come here as a criminal or to abuse our generosity..."

“... will prevent known criminals, failed and deported refugee claimants and other deportees using fake identity..."

(Kenney, 2012)

The second lexis found in this discourse has to do with the juxtaposition between fake and real refugees, frequently using the words 'bogus' and 'bona fide.' The word 'bogus' is particularly familiar, being used eight times in this short speech, but also particularly troubling. The language of 'bogus' and 'fraudulent' associated with refugee claimants implies a violation of the norms and the law before any official determination has been made. This criminalization of refugees reinforces the law-abiding versus criminal dichotomy which feeds the 'migrants as a threat' discourse. There is also a separation of those people who need Canada's help and those people who do not. According to this rhetoric, claimants from a country on the DCO list are deemed not in need of Canada's protection since they have democratic government and respect human rights. 
“...asylum seekers are found to have bogus claims, claims that end up being rejected or withdrawn."

"Bill C-31 will facilitate legitimate travel to Canada by bona fide visitors, students, businesspeople and others."

"...providing much swifter protection for real refugees."

"...will result in faster protection for real refugees and quicker removal of bogus refugee claimants."

"... reduce the options available to bogus claimants to delay their removal from Canada..."

"...the cost to Canadian taxpayers for bogus asylum claimants..."

"...organized waves of fake claims from safe democratic countries..."

"....contributing to pull factors for bogus claims."

“...if you are a bona fide refugee you're going to get protection in Canada."

"...on people who are not in need of our protection, at the expense of legitimate asylum seekers..."

"At the same time, those who truly need our help will get it even faster." (Kenney, 2012)

In addition, there is a constant association with DCO claimants and manifestly unfounded claims, both of which are denied access to the RAD. This is deciding ahead of time that a group of people, all with different basis of claims, is more doubtful than others, in a clear act of discrimination and otherness. The Canadian government's formulaic portrayal of immigrants and refugees perpetuates an us/them divide where personal circumstances are ignored (Gilbert, 2013b). Otherness is therefore used to police the threat of foreignness in liberal democracy and to maintain "positional superiority" (Saïd, 1996, p. 7). Representations of refugees as criminal others has allowed the government to impose measures that limit the rights of groups of people.

At the time of the visa implication in 2009, Mexican refugee claimants represented well over $25 \%$ of total claims received and the acceptance rate of claims from Mexico was only 11\% (CIC, 2009). The low acceptance rate of such high number of claimants made it easy to frame the influx of Mexican refugees as a security crisis, not for the human security of people fleeing violence and persecution, but for the human security of Canadians. By 
that time, rhetorical distortions had already criminalized Mexicans as "abusers" of the Canadian refugee system. These "abusers", according to Kenney, are "people who do not need [Canada's] protection," a political rationality that has led to the DCO policy. The designation of Mexico is based on the constructed knowledge that Mexicans are not in need of protection despite high levels of violence and human rights abuse, often perpetrated by the state. This is in line with Gilbert (2013a) who argues that through this construct of allege abuse, politicians have reduced a complex migration condition to "bogus" claims, trivialized refugee and human rights, and failed to appreciate Mexico’s “complex political reality" (p. 154).

\section{Ministerial Power - An Open Door For Biased Decisions}

The safe country of origin concept that has been incorporated into the Canadian refugee system is unjust and problematic for many reasons. First and foremost, the basis of nationality should not be a determinant of how a refugee is treated. Many argue that the Bill violates the basic principles of justice with such provisions as mandatory detention without review, limited access to Refugee Appeal Division (RAD) and the faster timelines and retroactive application of the DCO policy. One of the most troubling components of Canada's interpretation of the DCO policy is that the power to designate a country safe rests solely in the hands of the Minister, leaving such decisions open to inappropriate political considerations (Neve, 2008; Neve, 2012). Even if the DCO country review pointed out the numerous human rights abuses and lack of state protection mechanisms, the Minister at the time, Jason Kenney, still designated Mexico as a safe country. This is because there is no law holding the Minister responsible for following the advice of the country review. As mentioned in Chapter 4, the requirement of a positive recommendation from a panel of human rights experts in order to make a designation was removed from 
legislation as part of the amendments in Bill C-31. An in-depth country review is conducted but the Minister is not required to follow the advice set forth in the review. The recommendation for the minister to follow such advice is now set out in policy rather than legislation, an approach justified by the greater flexibility allowed. With the power to designate countries without a positive recommendation from a panel of experts, the Minister no longer has to follow the advice given in the country review (CIC, RAB, 2012a). This leaves the designation of countries open to various biases, including diplomatic and economic reasons. The Minister is a political official, subject to diplomatic pressures and political persuasion. This is consistent with Gilbert (2013a) who infers that Minister Kenney's position on alleged "bogus" claimants could be perceived as political interference as he is creating systematic discrimination and prejudice against a targeted group of claimants, an inhumane discernment on the Government of Canada's behalf. There is no doubt that Mexico's designation was a clear example of partisan decisionmaking in line with Harper's Conservative government. Giving arbitrary power to a single Minister to designate safe countries of origin has opened the door to decisions based on partisan interests, which affect Canada's foreign policy directives.

Since the establishment of diplomatic relations in 1944, Mexico and Canada's relationship has revolved around trade and diplomacy. The development of new migration streams from Mexico to Canada has largely stemmed from rising economic integration under the North American Free Trade Agreement (NAFTA). After NAFTA's implementation in 1994, trade between Canada and Mexico increased dramatically. Even today, Canada remains Mexico's largest trading partner after the United States and Mexico is Canada's third largest trading partner after the United States and China (Massey \& Brown, 2011). Among the data provided through the Access to Information and transcripts 
of Standing Committees regarding Bill C-31 are suggestions that the DCO policy is because of trade agreements. This is particularly relevant to a country like Mexico that is experiencing a deepening human rights crisis while remaining high-level diplomatic and economic partners with Canada.

As part of the country review process (described in Chapter 4), an Interdepartmental Working Group is established to discuss the DCO Country Reviews and to provide input on considerations relevant to advice on a designation recommendation. In one document regarding the process for providing ministerial advice on designation, the considerations to be taken into account are listed and include, “...considerations related to the overall impact of designation on the department and partners, e.g. visa policy, trade and diplomatic impacts" (CIC, RAB, 2012c). The designation of Mexico is an example that fits these "considerations," particularly the impact of designation or non-designation on trade and diplomacy. Giving the Minister absolute power of designation allows countries to be labeled safe based on the diplomatic relations and benefits to Canada rather than the actual human rights record.

This approach also undermines one of the most fundamental principles of refugee protection, namely that refugee claimants should have their cases assessed individually, not on the basis of sweeping generalizations such as the countries from which they come from (Neve, 2012). It is a discriminatory practice to treat refugees based on the country they are claiming from, especially when it comes to barring fundamental rights such as access to healthcare and right to appeal. Many critics declare that designating Mexico a "safe" country is denying the human rights crisis created by the violent drug wars and the erosion of the power of the state to protect and proves discriminatory towards many Mexicans (Gilbert, 2013b; Neve, 2008; Wright, 2012). 


\section{CHAPTER 6: CONCLUSION}

The recent designation of Mexico as a 'safe' country is fraught with questions and dilemmas, many of which this study has only but touched on. After exploring the designation process and applying it to the case of Mexico, I can answer the research question of whether or not Mexico belongs on the DCO list with a resounding NO. The addition of Mexico to the list of Designated Countries of Origin was based not on the conditions of the country, but rather on diplomacy and economic favour. This answer, however, remains subject to opinion due to the lack of transparency regarding designation and country reviews. I firmly believe that the designation of Mexico was a result of the fatally flawed ministerial policy, which leaves designations open to political influence and diplomatic pressures, and the oppressive neoliberal government discourse that criminalizes refugee claimants.

For a more complete analysis of this discriminatory policy and it's application to Mexico, one must also take into consideration the influence of the well-established immigration nexus between Mexico and the United States and the recent militarization of the American border. This study was also limited to government discourse and did not explore the media's role in the criminalization of refugees.

The exploration of the DCO policy and Mexico's designation in this study led to many additional questions, specifically regarding the high rejection rate of Mexican refugees during years of peak drug violence. In order to create awareness necessary to evoke change, this incidence of prejudiced rejection must be investigated further.

\section{Recommendations}

The concept of designated countries of origin is an equivocation which contradicts the fundamental principle that refugee claims should be assessed individually. At its very 
core, the DCO policy constitutes indefensible discrimination. The basis of nationality should not determine how a refugee, or any human being, is treated. In a perfect world, the DCO policy would be completely removed from legislation. However, it is unlikely that this will change in Canada.

If the DCO policy is here to stay, there are many changes that need to take place in order for Canada's refugee system to be called fair. First and foremost, the decision to designate a safe country must be made, and approved, by a panel of experts. The determination of country conditions with the purpose of defining a country safe is an intricate decision that should require the consideration of a multitude of human rights reports and cases. The decision-making power should not be left solely in the hands of a Minister open to political influence. In addition, the process of designating a safe country, the country review, and the final data used to designate a country should be transparent and accessible. Designations should also be open to challenge in a court of law, and review in the case of changing conditions in the country of origin. This would be more likely to happen if the designation of a country were made by a panel of experts, rather than a political official. Finally, the various limitations placed on refugees from DCOs, such as insufficient timelines for the BOC and hearing, lack of access to health care, and no access to the RAD, are unjust and wrong and must be removed. The intent of Canada's refugee system is to ensure that people will be protected from serious human rights violations. However, barring access to justice and denying any human being healthcare are human rights violations themselves. The designated countries of origin policy is blatant discrimination and has no place in Canadian legislation. 


\section{Coding Table 1}

\begin{tabular}{|c|c|c|}
\hline Variable \# & Variable Name & Values/ Descriptions \\
\hline \multicolumn{3}{|c|}{ Structural Variables } \\
\hline 1 & case id & $\begin{array}{l}\text { case id number begins with } \mathrm{G} \text { for government, } \\
\text { then the type of text being coded }(\mathrm{e}=\text { email, } \mathrm{m}= \\
\text { memo, } \mathrm{r}=\text { report, } \mathrm{sp}=\text { speaking notes, } \mathrm{bn}= \\
\text { briefing notes, } \mathrm{a}=\text { analyses, } \mathrm{ms}=\text { records of } \\
\text { meetings/minutes of meetings, o = other } \\
\text { communication ), followed by sequential number; } \\
\text { Ge1, Ge2; Gsn } 1, \mathrm{Gsn} 2 \text {, etc. }\end{array}$ \\
\hline 2 & type & $\begin{array}{l}1=\text { email } \\
2=\text { memo } \\
3=\text { report } \\
4=\text { speaking notes } \\
5=\text { briefing notes } \\
6=\text { analyses } \\
7=\text { records of meetings/minutes of meetings } \\
8=\text { other communication (specify) }\end{array}$ \\
\hline 3 & date & yy/mm \\
\hline 4 & $\begin{array}{l}\text { level of government } \\
\text { (or speaker/author) }\end{array}$ & $\begin{array}{l}1=\mathrm{DM} \\
2=\mathrm{ADM} \\
3=\mathrm{DG} \\
\text { etc. }\end{array}$ \\
\hline \multicolumn{3}{|c|}{ Substantive Variables } \\
\hline 5 & list of DCOs & $\begin{array}{l}\text { Is the communication regarding the first list of } \\
\text { DCOs or the second? } \\
1=\text { first list } \\
2 \text { = second list } \\
3 \text { = unclear }\end{array}$ \\
\hline 6 & Mexico & $\begin{array}{l}\text { Is Mexico mentioned in the communication? } \\
1=\text { Yes } \\
2 \text { = No } \\
\text { examples/quotes: }\end{array}$ \\
\hline 7 & security & $\begin{array}{l}\text { Are issues of security raised? } \\
1=\text { Yes } \\
2=\text { No } \\
\text { examples/quotes: }\end{array}$ \\
\hline 8 & "real" refugees & $\begin{array}{l}\text { Is language concerning "real" refugees used? } \\
1=\text { Yes } \\
2=\text { No } \\
\text { examples/quotes: } \\
\text { (keywords to search for: real, true, actual, bona } \\
\text { fide, genuine, authentic, deserving, valid }\end{array}$ \\
\hline
\end{tabular}




\begin{tabular}{|c|c|c|}
\hline$\overline{9}$ & "fake" refugee & $\begin{array}{l}\text { Is language concerning "fake" refugees used? } \\
1=\text { Yes } \\
2=\text { No } \\
\text { examples/quotes: } \\
\text { (keywords to search for: bogus, fake, false, } \\
\text { phony, sham, scam, queue-jumper, criminal, } \\
\text { illegitimate, etc.) }\end{array}$ \\
\hline 10 & state protection & $\begin{array}{l}\text { Is the ability for a country to provide protection } \\
\text { addressed? } \\
1=\text { Yes } \\
2 \text { = No } \\
\text { examples/quotes: }\end{array}$ \\
\hline 11 & human rights & $\begin{array}{l}\text { Are issues of human rights addressed? } \\
1=\text { Yes } \\
2=\text { No } \\
\text { examples/quotes: }\end{array}$ \\
\hline 12 & violence & $\begin{array}{l}\text { Is violence talked about? } \\
1=\text { Yes } \\
2=\text { No } \\
\text { examples/quotes: }\end{array}$ \\
\hline 13 & narco-trafficking & $\begin{array}{l}\text { Is narco-trafficking mentioned? } \\
1=\text { Yes } \\
2=\text { No } \\
\text { examples/quotes: }\end{array}$ \\
\hline
\end{tabular}




\section{Coding Table 2}

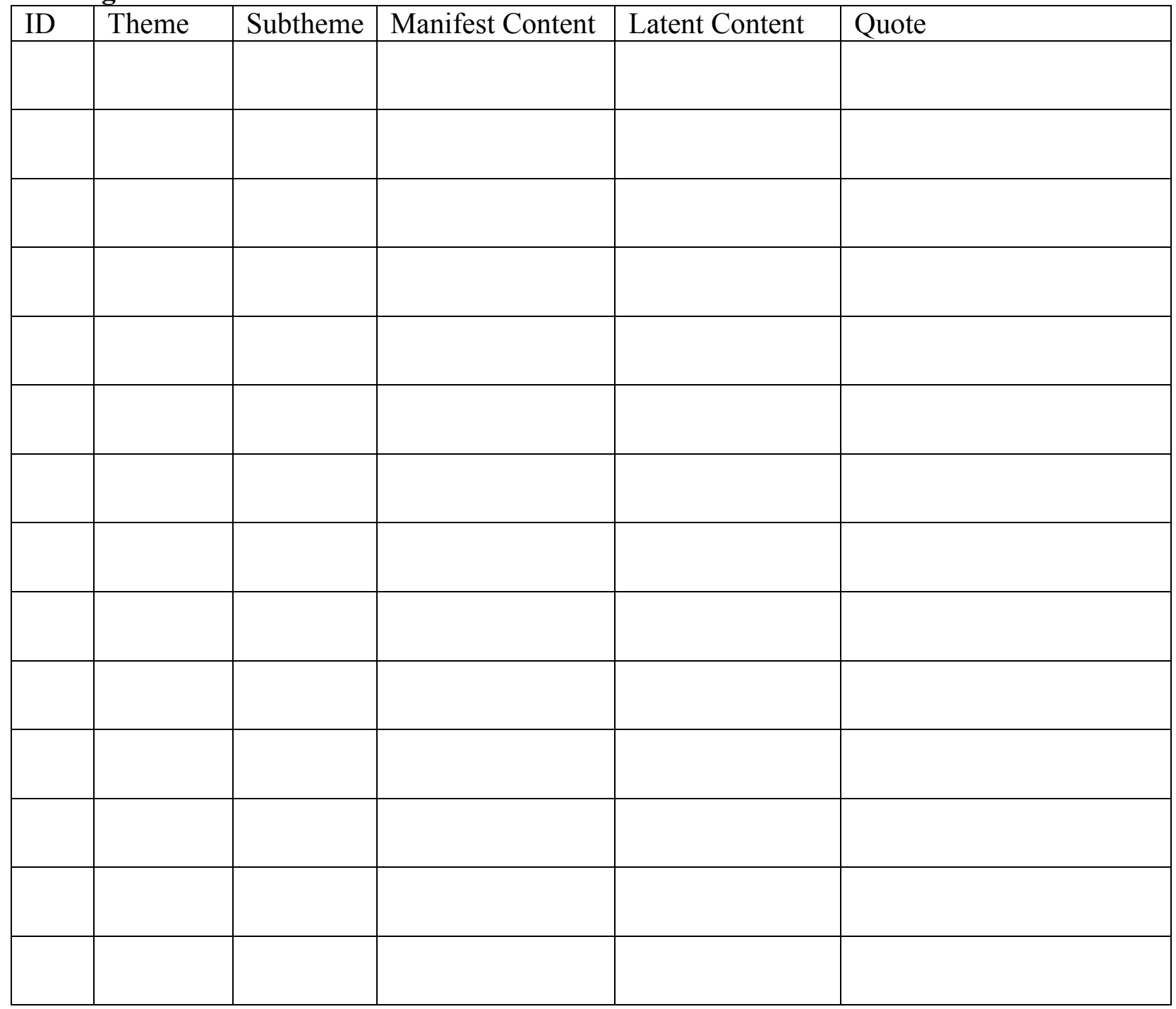


Figure 1

\section{APPENDIX B}

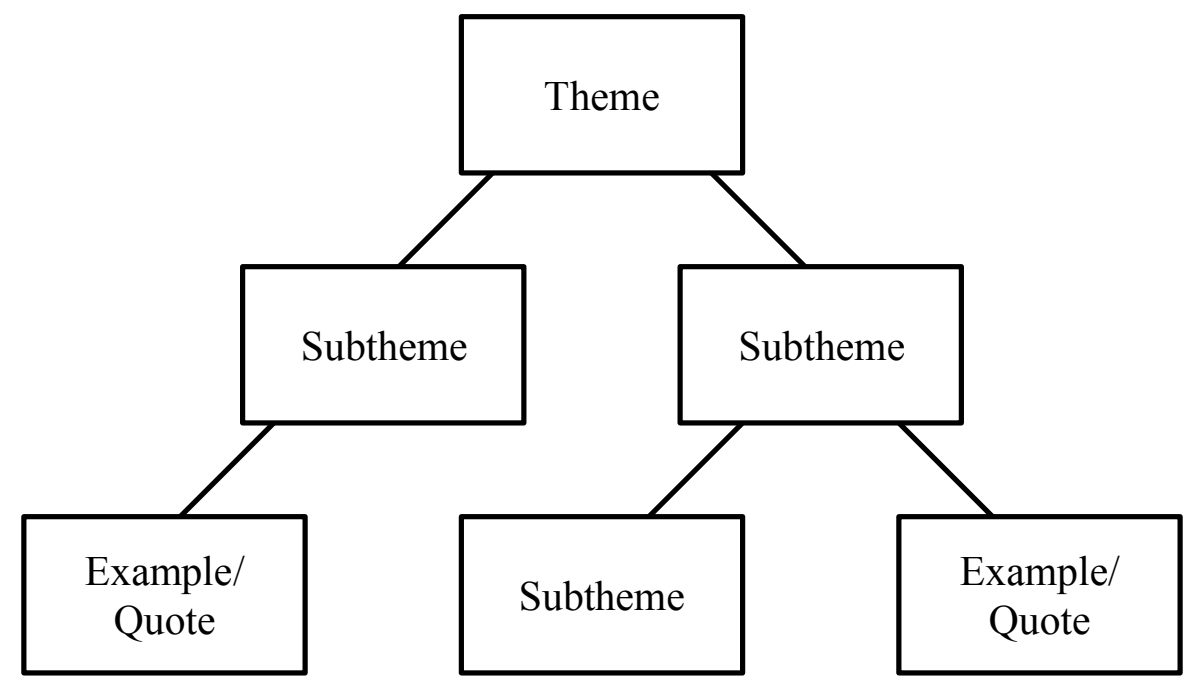

Figure 2

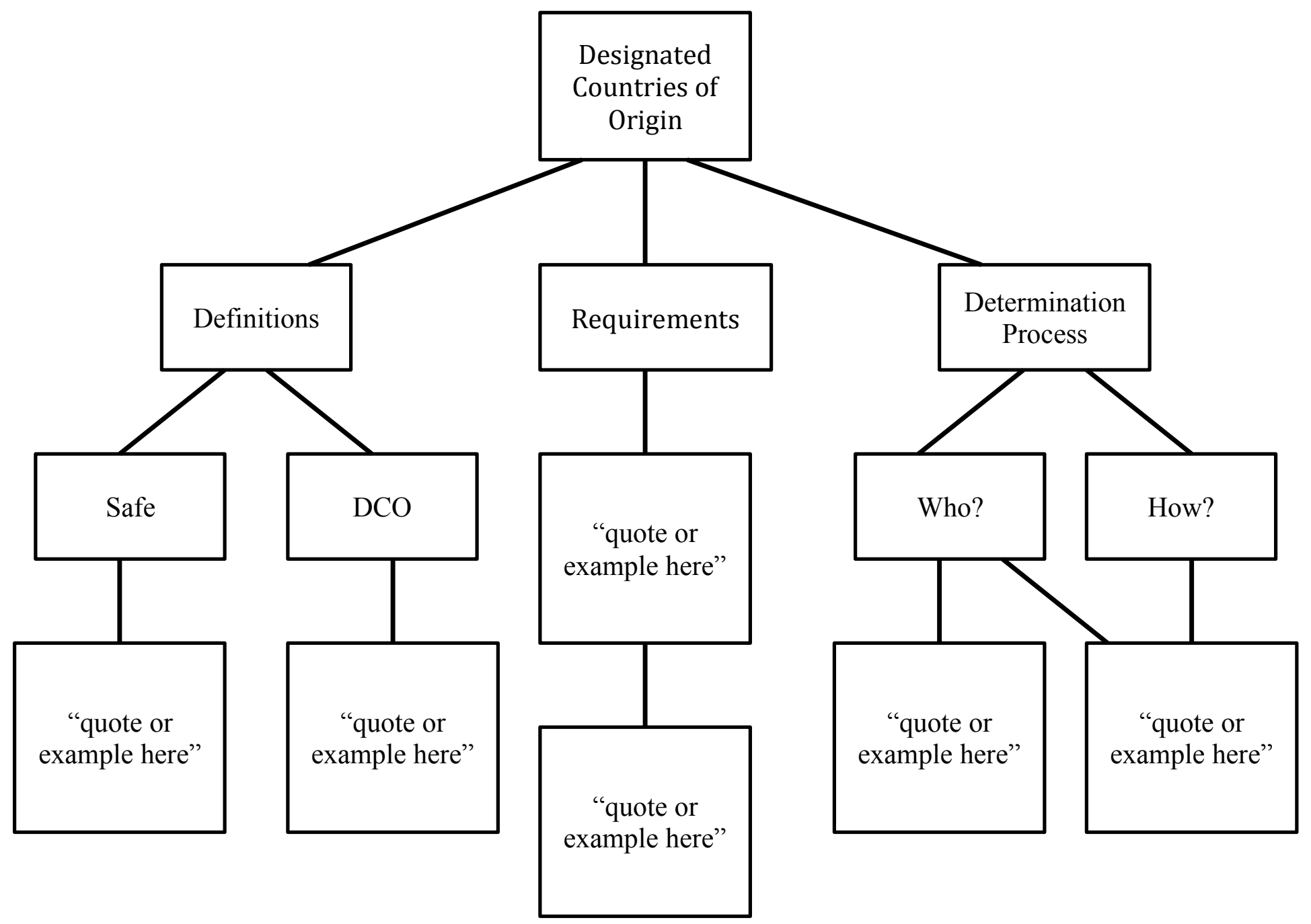




\section{REFERENCES}

Abizaid Bucio, O. (2004). The Canada-Mexico Relationship: The Unfinished Highway. Canadian Foundation for the Americas, FOCAL policy paper, 1-16.

Amnesty International. (2013). Informe anual 2012: El estado de los derechos humanos en el mundo, México. Retrieved from http://www.amnesty.org/es/region/mexico/report2012

Amnesty International. (2012a). Annual Report 2011 - Mexico. Retreived from http://www.amnesty.org/en/region/mexico/report-2011

Amnesty International. (2012b, May 21). Mexico: Freedom of expression still under attack as six journalists killed. Amnesty International News. Retrieved from http://www.amnesty.org/en/news/mexico-freedom-expression-still-under-attack-sixjournalists-killed-2012-05-21

Associated Press (AP). (2012, June 14). Mexican police appear on video kidnapping murder victims. CBC News World. Retrieved from http://www.cbc.ca/news/world/mexican-police-appear-on-video-kidnapping-murdervictims-1.1133374

Archer, K. \& Berdahl, L. (2011). Explorations: Conducting Empirical Research in Canadian Political Science ( $2^{\text {nd }}$ Edition). Don Mills, Ontario: Oxford University Press.

Bastia, T. (2014). Intersectionality, migration, and development. Progress in Development Studies, 14(3), 237-248.

Betts, A. (2010). The Refugee Regime Complex. Refugee Survey Quarterly. 29(1), 12-37.

Bowden, C. (2011). Murder City: Ciudad Juarez and the Global Economy's New Killing Fields. New York, NY: Nation Books.

Buchanan, H. (2010). Fleeing the Drug War Next Door: Drug-related Violence as a Basis for Refugee Protection for Mexican Asylum-Seekers. Merkourios, 27(72), 28-60.

Burnett, J., Peñaloza, M., and Benincasa, R. (2010, May 19). Mexico Seems To Favor Sinaloa Cartel In Drug War. NPR. Retrieved from http://www.npr.org/2010/05/19/126906809/mexico-seems-to-favor-sinaloa-cartel-indrug-war

Buzan, B., Wæver, O., and Wilde, J. (1998). Security: A New Framework for Analysis Boulder. Colorado: Lynne Rienner Publishers.

Campbell, C. (2003). Anti-oppressive theory and practice as the organizing scheme for social work practice. Canadian Social Work Review, 20(1), 121-125. 
Canada. Parliament. House of Commons. Standing Committee on Citizenship and Immigration. (2012a). Supplementary Estimates Notes Re: Bill C-31: Designated Countries of Origin. $41^{\text {st }}$ Parliament, $1^{\text {st }}$ session.

Canada. Parliament. House of Commons. Standing Committee on Citizenship and Immigration. (2012b). Refugee Reform under Bill C-31, Questions and Answers for Committee Appearances. $41^{\text {st }}$ Parliament, $1^{\text {st }}$ session.

Canadian Council for Refugees (CCR). (2014). 2013 Refugee Claim Data and IRB Member Recognition Rates. Retrieved from https://ccrweb.ca/en/2013-refugee-claim-data

Canadian Council for Refugees (CCR). (2013). 2012 Refugee Claim Data and IRB Member Recognition Rates. Retrieved from https://ccrweb.ca/en/2012-refugee-claim-data

Canadian Council for Refugees (CCR). (2012). 2011 Refugee Claim Data and IRB Member Recognition Rates. Retrieved from https://ccrweb.ca/en/2011-updated-refugee-claimdata

Canadian Council for Refugees (CCR). (2011). 2010 Refugee Claim Data and IRB Member Recognition Rates. Retrieved from https://ccrweb.ca/en/2010-refugee-claim-data

Citizenship and Immigration Canada (CIC). (2013a). Designated Countries of Origin. Retrieved from http://www.cic.gc.ca/english/refugees/reform-safe.asp

Citizenship and Immigration Canada (CIC). (2013b). Health care - Refugees. Retrieved from http:/www.cic.gc.ca/english/refugees/outside/arriving-healthcare.asp

Citizenship and Immigration Canada (CIC). (2012). Facts and Figures 2012, Immigration overview-Permanent and temporary residents. Retrieved from http://www.cic.gc.ca/english/resources/statistics/menu-fact.asp

Citizenship and Immigration Canada (CIC). (2009). Backgrounder - The Visa Requirement for Mexico. Retrieved from http:/www.cic.gc.ca/english/DEPARTMENT/media/backgrounders/2009/2009-0713.asp?_ga=1.174427296.368061387.1398120647

Citizenship and Immigration. Monitoring, Analysis, and Country Assessment Division. (2012a). Criteria and Indicators for Designated Country of Origin (DCO) Country Reviews. [Ottawa]: Author.

Citizenship and Immigration Canada. Monitoring, Analysis, and Country Assessment Division. (2012b). Designated Country of Origin: Country Review Criteria. [Ottawa]: Author.

Citizenship and Immigration Canada. Refugee Affairs Branch. (2012a). Question Period Note: Designated Countries of Origin. [Ottawa]: Author. 
Citizenship and Immigration Canada. Refugee Affairs Branch. (2012b). Question Period Note: Designated Countries of Origin. [Ottawa]: Author.

Citizenship and Immigration Canada. Refugee Affairs Branch. (2012c). Designated Countries of Origin: Proposed Process for Providing Ministerial Advice. [Ottawa]: Author.

Collacott, M. (2010). Reforming the Canadian refugee determination system. Refuge, 27(1), $110-118$.

Comisión Mexicana de Defensa y Promoción de los Derechos Humanos (CMDPDH). (2012). Arraigo made in Mexico: A violation to human rights. Retrieved from http://tbinternet.ohchr.org/Treaties/CAT/Shared\%20Documents/MEX/INT_CAT_NG O_MEX_12965_E.pdf

Consejo Ciudadano para la Seguridad Pública y la Justicia Peanl (CCSPJP). (2013, Feb. 7). San Pedro Sula otra vez la ciudad más violenta del mundo; Acapulco, la segunda. Retrieved from http://www.seguridadjusticiaypaz.org.mx/sala-de-prensa/759-sanpedro-sula-otra-vez-la-ciudad-mas-violenta-del-mundo-acapulco-la-segunda

Consejo Ciudadano para la Seguridad Pública y la Justicia Peanl A.C. (CCSPJP). (2012, Jan. 11). San Pedro Sula, la ciudad más violenta del mundo; Juárez, la segunda. Retrieved from http://www.seguridadjusticiaypaz.org.mx/sala-de-prensa/541-sanpedro-sula-la-ciudad-mas-violenta-del-mundo-juarez-la-segunda

Dalrymple, J. \& Burke, B. (2006). Anti-oppressive Practice: Social Care and the Law. Berkshire, England: Open University Press.

Department of Justice Canada. Public Safety, Defence, and Immigration Portfolio. (2012). Recent Reform to the Immigration System - C-11, C-31 - Extent to Which Appeal, PRRA, JR, is Available for Individuals Not Granted Protected Person Status. [Ottawa]: Author.

Díez, J. (2008). Mexico and North American Security. In Drache, D. (Ed.), Big Picture Realities: Canada and Mexico at the Crossroads (pp. 153-168). Waterloo: Wilfred Laurier University Press.

The Economist. (2013, Oct. 19). Crime in Mexico: Out of sight, not out of mind. Retrieved from http://www.economist.com/news/americas/21588071-having-decided-playdown-fight-against-drug-kingpins-enrique-pe-nieto-has-yet-come

Esses, V., Veenvliet, S., and Hodson, H. (2008). Justice, Morality, and the Dehumanization of Refugees. Social Justice Research, 21, 4-25. 
Foucault, M. (1980). Two lectures. In C. Gordon, (Ed.), Power/Knowledge: Selected Interviews and Other Writings, Michel Foucault, 1972-1977 (pp. 78-108). Brighton: The Harvester Press.

Gilbert, L. (2013a). Canada's Visa Requirement For Mexicans and Its Political Rationalities. Norteamérica, 8(1), 139-161.

Gilbert, L. (2013b). The Discursive Production of a Mexican Refugee Crisis in Canadian Media and Policy. Journal of Ethnic and Migration Studies, 39(5), 827-843.

Gómora, D. (2012, January 2). Narco controla 71.5\% de los municipios del país. El Universal. Retreived from http://www.eluniversal.com.mx/nacion/192540.html

Government of Canada. (2014). Mexico - Travel Advisories. Retrieved from http://travel.gc.ca/destinations/mexico

Harville, B. (2012). Ensuring Protection or Opening the Floodgates: Refugee Law and Its Application to Those Fleeing Drug Violence in Mexico. Georgetown Immigration Law Journal, 27(135), 135-185.

Ibrahim. M. (2005). The Securitization of Migration: A Racial Discourse. International Migration, 43(5), 163-187.

Immigration and Refugee Board (IRB). (2011). Refugee Status Determinations (19892011). Human Rights Research and Education Centre-Refugee Forum. Retrieved from http://www. cdp-hrc.uottawa.ca/projects/refugeeforum/projects/documents/ REFUGEESTATS COMPREHENSIVE1999-2011.pdf

Immigration and Refugee Protection Act (IRPA) (2001, c. 27). Retrieved from http://laws.justice.gc.ca/eng/acts/i-2.5/

Kenney, J. (2012). Minister of Citizenship, Immigration and Multiculturalism Jason Kenney Holds a News Conference to Announce Next Steps in Protecting Canada's Immigration System transcription. Ottawa: Media Q Inc.

Massey, D. and Brown, A. (2011). Movement between Mexico and Canada: Analysis of a New Migration Stream. International Migration, 6(1), 119-144.

Molzahn, C., Rodriguez, O., and Shirk, D. (2013). Drug Violence in Mexico: Data and Analysis through 2012. Transborder Institute, University of San Diego. Retrieved from http://justiceinmexico.files.wordpress.com/2013/02/130206-dvm-2013-final.pdf

Nederveen Pieterse, J. (2002). Europe and its Others. In Golberg D. and Solomos J. (Eds.) A Companion to Racial and Ethnic Studies (pp. 17-24). Malden, MA: Blackwell Publishers. 
Neuman, W.L. (2011). Basics of Social Research: Qualitative and Quantitative Approaches. Boston, MA: Pearson.

Neve, A. (2012). Human Rights and Refugee Groups Hold a News Conference to Provide Arguments on Why Bill C-31 should be Withdrawn or Defeated at Second Reading transcription. Ottawa: Media Q Inc.

Neve, A. (2008). Rights at the Borders: Human Rights and Migration in the CanadaMexico Relationship. In D. Drache (Ed.), Big Picture Realities: Canada and Mexico at the Crossroads (pp.73-86). Waterloo: Wilfred Laurier University Press.

Poulton, R. (2010). Wondrous strange: a reply to the myth of the evil refugee. Refuge, 27(1), 119-122.

Reporters Without Borders. (2013). Mexico - World Report. Retrieved from http://en.rsf.org/report-mexico,184.html

Russo, R. M. (2008). Security, Securitization and Human Capital: The New Wave of Canadian Immigration Laws. International Journal of Human and Social Sciences. 3(4), 587-596.

Saïd, E. (1996). Orientalism. New York, NY: Vintage Books.

Sakamoto, I. \& Pitner, R. (2005). Use of Critical Consciousness in Anti-Oppressive Social Work Practice: Disentangling Power Dynamics at Personal and Structural Levels. The British Journal of Social Work, 35(4), 435-452.

Santa-Cruz, A. (2012). Canada-Mexico Relations: Interdependence, Shared Values and the Limits of Cooperation. American Review of Canadian Studies, 42(3), 401-417.

Secretaría de Gobernación (SEGOB). (2012, April 16). Programa Nacional para Prevenir y Eliminar la Discriminación 2012. Diario Oficial de la Federación, SEGOB. Retrieved from http://www.dof.gob.mx/nota_detalle.php?codigo $=5243829 \&$ fecha $=16 / 04 / 2012$

Squires, J. (2008). Intersecting inequalities: Reflecting on the subjects and objects of equality. The Political Quarterly, 79, 53-61.

Stevenson, M. (2011, August 12). Mexican Police Guilty Of Widespread Abuse: Human Rights Commission. Huffington Post. Retrieved from http://www.huffingtonpost.com/2011/08/12/mexican-police-abuse_n_925856.html

Trimble, L. and Treiberg, N. (2011). Content Analysis. In Archer, K. and Berdahl, L. (Eds.), Explorations: Conducting Empirical Research in Canadian Political Science (pp. 212-222). Don Mills, Ontario: Oxford University Press 
Tuckman, J. (2012, December 6). Mexican police brutality uncovered by human rights investigators. The Guardian. Retrieved from http://www.theguardian.com/world/2012/dec/06/mexican-police-brutalitypresidential-inauguration

Universidad Nacional Autónoma de México (UNAM). (2012). Organizaciones No Gubernamentales en México. Catedra UNESCO de Derechos Humanos de la UNAM. Retrieved from http://132.247.1.49/catedra/index.php?option=com_content\&view $=$ article\&id $=1674 \&$ Itemid $=1072$

United Nations High Commission for Refugees (UNHCR). (1951/1967). Convention and Protocol Relating to the Status of Refugees. Retrieved from http://www.unhcr.org/3b66c2aa10.html

United Nations High Commission for Refugees (UNHCR). (2012). UNHCR Submission on Bill C-31, Protecting Canada's Immigration System Act. Retrieved from http://www.unhcr.ca/resources/documents/RPT-2012-05-08-billc31-submission-e.pdf

Vulliamy, E. (2010). Amexica: War Along the Borderline. New York, NY: Farrar, Straus and Giroux.

Weisbrot, M. (2012, July 9). Irregularities Reveal Mexico's Election Far from Fair. The Guardian. Retrieved from http://www.theguardian.com/commentisfree/2012/jul/09/irregularities-reveal-mexicoelection-far-from-fair

Wright, M. (2012). Wars of Interpretations. Antipode, 44(3), 564-580.

Zúñiga, J. (2013, October 1). Cifra negra de secuestros es 98\% mayor a las denuncias. La Jornada. p. 17. Retrieved from http://www.jornada.unam.mx/2013/10/01/politica/017n1pol

\section{Access to Information Request emails}

E. Bauman, internal communication, February 17, 2012

E. Bauman, internal communication, March 1, 2012

E. Bauman, internal communication, March 30, 2012

D. Cashaback, internal communication, May 8, 2012

U. Chauhan, internal communication, March 29, 2012a

U. Chauhan, internal communication, March 29, 2012b 
M. Davidson, internal communication, February 15, 2012

C. Kunz, internal communication, March 7, 2012

E. Lazar, internal communication, February 24, 2012

E. Lazar, internal communication, March 8, 2012.

P. Norton, internal communication, February 24, 2012

E. Pease, internal communication, May 8, 2012 